\title{
Mycobacterium tuberculosis complex in wildlife: Review of current applications of antemortem and postmortem diagnosis
}

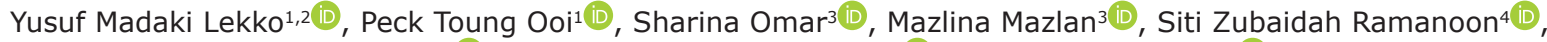 \\ Sabri Jasni ${ }^{5}$ (D) Faez Firdaus Abdullah Jesse ${ }^{1}$ (D) and Azlan Che-Amat ${ }^{1}$ (D)
}

1. Department of Veterinary Clinical Studies, Faculty of Veterinary Medicine, Universiti Putra Malaysia, 43400 UPM

Serdang, Selangor, Malaysia; 2. Department of Veterinary Medicine, Faculty of Veterinary Medicine, University of Maiduguri, 1069 PMB, Maiduguri, Borno State, Nigeria; 3. Department of Veterinary Pathology and Microbiology, Faculty of Veterinary Medicine, Universiti Putra Malaysia, 43400 UPM Serdang, Selangor, Malaysia; 4. Department of Farm and

Exotic Animal Medicine and Surgery, Faculty of Veterinary Medicine, Universiti Putra Malaysia, 43400 UPM Serdang, Selangor, Malaysia; 5. Department of Paraclinical, Faculty of Veterinary Medicine, Universiti Malaysia Kelantan, Pengkalan Chepa, 16100 Kota Bharu, Kelantan, Malaysia.

Corresponding author: Azlan Che-Amat, e-mail: c_azlan@upm.edu.my

Co-authors: YML: ymlekko@unimaid.edu.ng, PTO: ooi@upm.edu.my, SO: sharina@upm.edu.my,

MM: m_mazlina@upm.edu.my, SZR: sramanoon@upm.edu.my, SJ: jasni@umk.edu.my, FFAJ: jesse@upm.edu.my Received: 29-02-2020, Accepted: 16-07-2020, Published online: 09-09-2020

doi: www.doi.org/10.14202/vetworld.2020.1822-1836 How to cite this article: Lekko YM, Ooi PT, Omar S, Mazlan M, Ramanoon SZ, Jasni S, Jesse FFA, Che-Amat A (2020) Mycobacterium tuberculosis complex in wildlife: Review of current applications of antemortem and postmortem diagnosis, Veterinary World, 13(9): 1822-1836.

\begin{abstract}
Tuberculosis (TB) is a chronic inflammatory and zoonotic disease caused by Mycobacterium tuberculosis complex (MTBC) members, which affects various domestic animals, wildlife, and humans. Some wild animals serve as reservoir hosts in the transmission and epidemiology of the disease. Therefore, the monitoring and surveillance of both wild and domestic hosts are critical for prevention and control strategies. For TB diagnosis, the single intradermal tuberculin test or the single comparative intradermal tuberculin test, and the gamma-interferon test, which is regarded as an ancillary test, are used. Postmortem examination can identify granulomatous lesions compatible with a diagnosis of TB. In contrast, smears of the lesions can be stained for acid-fast bacilli, and samples of the affected organs can be subjected to histopathological analyses. Culture is the gold standard test for isolating mycobacterial bacilli because it has high sensitivity and specificity compared with other methods. Serology for antibody detection allows the testing of many samples simply, rapidly, and inexpensively, and the protocol can be standardized in different laboratories. Molecular biological analyses are also applicable to trace the epidemiology of the disease. In conclusion, reviewing the various techniques used in MTBC diagnosis can help establish guidelines for researchers when choosing a particular diagnostic method depending on the situation at hand, be it disease outbreaks in wildlife or for epidemiological studies. This is because a good understanding of various diagnostic techniques will aid in monitoring and managing emerging pandemic threats of infectious diseases from wildlife and also preventing the potential spread of zoonotic TB to livestock and humans. This review aimed to provide up-to-date information on different techniques used for diagnosing TB at the interfaces between wildlife, livestock, and humans.
\end{abstract}

Keywords: culture, ELISA, gamma interferon test, genotyping, histopathology, Mycobacterium tuberculosis complex, polymerase chain reaction, wildlife.

\section{Introduction}

Tuberculosis (TB) is a reemerging and chronic infectious disease caused by Mycobacterium tuberculosis complex (MTBC); it affects livestock, wildlife, and humans [1]. The disease has a major economic impact on livestock production, due to costs associated with testing and slaughtering affected livestock. As such, bovine TB is subjected to control and eradication programs in some developing countries [1-4]. Studies have shown that one in every three people living today is infected with Mycobacterium tuberculosis, inducing increased morbidity and mortality in developing countries [5-9]. It was estimated that

Copyright: Lekko, et al. Open Access. This article is distributed under the terms of the Creative Commons Attribution 4.0 International License (http://creativecommons.org/licenses/by/4.0/), which permits unrestricted use, distribution, and reproduction in any medium, provided you give appropriate credit to the original author(s) and the source, provide a link to the Creative Commons license, and indicate if changes were made. The Creative Commons Public Domain Dedication waiver (http://creativecommons.org/ publicdomain/zero/1.0/) applies to the data made available in this article, unless otherwise stated.
1.2 million deaths from TB due to MTBC species and 143,000 new cases of zoonotic TB caused by Mycobacterium bovis occurred globally in the year 2018. However, only 16 countries reported the detection of $M$. bovis among pulmonary or extrapulmonary TB patients in 2018. Since 2007, TB has been the $10^{\text {th }}$ leading cause of death worldwide from a single infectious agent, ranking above HIV. Most cases in 2018 occurred in South East Asia (44\%), followed by Africa (24\%), the Western Pacific (18\%), the Eastern Mediterranean (8.1\%), the Americas (2.9\%), and then Europe $(2.6 \%)$ [10].

This review is intended to provide an up-to-date information of the antemortem and postmortem diagnostic techniques for $\mathrm{TB}$ at the interfaces between wildlife, livestock, and humans, that could help researchers and decision-makers to choose the most appropriate diagnostic protocol and to obtain a better understanding of their performance for effective TB surveillance and control strategies under different epidemiological situations in wild animals. 


\section{MTBC}

The members of MTBC are M. tuberculosis, M. bovis, M. bovis BCG (Bacillus, Calmette, and Guérin), M. africanum, M. microti, M. mungi, M. canetti, M. caprae, and M. pinnipedii [11-18]. Other members are Oryx bacillus [19], known as M. orygis [20], and the dassie bacillus [21]. The MTBC is recognized by $99.9 \%$ similarity at the nucleotide level, which resembles the 16S rRNA sequences [22].

\section{MTBC in Wildlife}

Over 40 free-ranging wild animal species are known to be infected with MTBC bacterial species, causing the disease. Host species may be "maintenance hosts" (infection persists without input from other sources) or "spillover hosts" (infection persists as long as there is input from an external source) [23]. Tuberculosis has been isolated from different types of wildlife, such as badgers, coyotes, raccoons, hares, rabbits, hedgehogs, brushtail possums, coatis, capybaras, lions, deer, elk, wild boars, foxes, primates and pinniped (gray seal) [24-26]. The Eurasian wild boar acts as a reservoir for TB in the Iberian Peninsula [27-31]. In addition, spillover transmission of MTBC to other wildlife species and domestic livestock has been reported in South African buffalo [32], leopards, hyenas, large-spotted genets, warthogs, bushpigs, eland, wildebeest, common duiker, honey badger, impala, lechwe, lions, cheetahs, chacma baboons, and greater kudu [32-36].

Reports of TB in wildlife, mainly in Asian elephants from various countries in Southeast Asia, have been published. For example in Thailand, M. tuberculosis was isolated from four Asian elephants by bacterial isolation and sequencing [25,37]. The MTBC has also been reported in an Asian elephant in Malaysia [38,39]. Reports have also been published from Thailand in 2010 of a captive Malayan tapir with disseminated TB caused by M. tuberculosis and confirmed by molecular methods [40]. In the British Isles, the European badger is the dominant reservoir host of TB [41]; in Australia, feral pigs, fallow deer, and water buffalo are the reservoir hosts, causing spillover transmission to domestic goats and cattle; while in North America (Michigan, Mexico), the hosts are white-tailed deer, but in Canada, they are whitetailed deer, wood bison, and elk. In New Zealand, the brushtail possum is causing the transmission to deer, ferrets, and cattle [28]. Studies showed that the lesions in wild animals appeared to be similar to those in domestic animals. However, there are variations in terms of the location and size of lesions in different affected animals $[42,43]$.

\section{Transmission}

Several factors influence the transmission of TB, including the number of infected animals, susceptible animals, routes of infection, anatomical location and lesions of disease, the structure of tuberculous lesions, pathogen shedding, and the infective dose in each infection route [44]. Environmental contamination is important for MTBC transmission [45]. Direct oral/nasal transmission is the major infection route, while indirect transmission routes are considered to be less important [46]. The thoracic and abdominal lesions suggest that MTBC is transmitted directly oro-nasally and indirectly through the environment through shared watering and feeding areas [47-49]. Though the indirect route of transmission is important for interspecies transmission through shared resources [50] is making the TB transmission within same species of animals becomes significance $[51,52]$. Drinking water points are critical risk areas for MTBC transmission, especially in semi-arid areas where there is a scarcity of water, which leads to the daily gathering of animals at water points [53]. Following excretion, the bacteria must withstand the environmental conditions for them to be fully pathogenic before they can infect susceptible hosts by indirect transmission [54].

\section{Antemortem Diagnosis of MTBC (Cell-mediated Immune [CMI] Response)}

For antemortem diagnosis, single intradermal tuberculin test (SITT), single comparative intradermal tuberculin test (SCITT), and gamma interferon test (IFN-y), which is regarded as a subsidiary test, are used [55-58]. These different analyses have their own shortcomings with regard to the results produced [59], but it is well accepted that they complement one another, especially when used synergistically; SCITT is regarded as a better diagnostic tool with the high specificity and moderate sensitivity, whereas the IFN-y test has higher sensitivity with the lower specificity [59-62]. Therefore, the two tests may not recognize a certain proportion of actually affected animals, leading to infection remaining in the animals [62-65]. The intradermal tuberculin test calculates dermal swelling basically due to CMI response $72 \mathrm{~h}$ after the introduction of purified protein derivative (PPD) in the skin of the neck or the caudal fold. The surface of the neck is more sensitive than the surface of the caudal fold; for this reason, more doses of PPD are required in the caudal fold region to increase it's sensitivity like that of neck region [66]. At the same time, the SCITT test correlates with the response against bPPD and is applied in the cervical region to increase the specificity [55].

The in vitro IFN- $\gamma$ assay involves two steps. In the first step, fresh blood samples are incubated to initiate the release of IFN- $\gamma$ by sensitized T lymphocytes. The second stage requires separating the plasma from the blood and observing the IFN- $\gamma$ in the plasma by an ELISA assay. A benefit of the IFN- $\gamma$ assay is that the interpretation criteria are adjusted to fit local situations, such as the epidemiological conditions, TB prevalence, and the extent of the local bovine TB control program. The IFN- $\gamma$ test has higher sensitivity than the skin test because the former detects TB disease in 
livestock as early as 14 days after infection [67] and 60-120 days faster than the SCITT test [68]. The most essential antigens used complementary to PPDs are the early secretory antigens (ESAT-6), culture filtrate protein 10 (CFP-10), and Rv3615c [69-73]. Moreover, the inclusion of Rv3020c increases the diagnostic sensitivity without affecting the specificity [74].

\section{Postmortem Diagnosis of MTBC}

\section{Direct smears}

For the rapid identification of MTBC infections, a direct smear is required for the detection of TB organisms from tissue samples with suspected infection followed by Ziehl-Neelsen (ZN) stain.. The basic principle of the stain is that MTBC available in the smear can take up an aryl methane dye, for example, carbol fuchsin, into the cell, resulting in acid-fast staining reaction, after treatment with a weak acid-alcohol solution. This is attributable to the mycolic acids that are present in the thick bacterial cell wall $[75,76]$. The detection of bacterial organisms from the tissues, feces, or other biological substances by this method is reduced because of few MTBC and possible contamination with other related organisms. Direct staining could not shed light on the members of the MTBC, producing the infection or show variation among viable and non-viable cells [76,77].

\section{Histopathology}

In free-ranging wildlife, the diagnosis of Mycobacterium spp. relies on gross findings and histopathological analyses. One reliable method is histopathological analysis with hematoxylin and eosin staining [77]. This technique has high specificity and the additional advantage of producing results within a few days. A correlation of $94 \%$ was found between the results obtained using histopathological analysis and culture methods, regarding an agreement on the diagnosis of M. bovis infection in cattle [78].

\section{Bacterial culture}

Culture is regarded as the gold standard technique for diagnosing MTBC, as described previously $[79,80]$, given its high specificity. However, it can occasionally produce false-negative results, and its sensitivity has reach only as high as $80 \%[81,82]$. Pre-treatment and processing procedures such as homogenization, decontamination, and concentration, as well as culture media that prevent the growth of contaminating bacteria, are required for the successful isolation of MTBC bacteria [83]. Critical factors for successful culture growth are the decontamination methods employed in the process, the type of decontaminant, and the concentration of decontaminant [84]. Decontaminants that are commonly used for this purpose are cetylpyridinium chloride and benzalkonium chloride [85], oxalic acid [86,87], sulfuric acid [88], and sodium hydroxide [85].

For the isolation of mycobacteria, three types of media are typically used. The first is egg-based media, such as Stonebrink's medium and Lowenstein-Jensen, with either glycerol or pyruvate. The second is agarbased media, such as Middlebrook 7H10 and 7H11, and tuberculosis blood agar medium, B83. The third type is liquid media, such as Middlebrook 7H9. The use of solid and liquid media together should maximize the sensitivity, an approach that has been approved for the isolation of mycobacteria in laboratories for human TB diagnosis globally [89-92]. There are limitations in the use of solid media for the screening of mycobacteria, although improvements have been made regarding the detection time and recovery rate through the use of broth-based culture systems, such as BACTEC 460, the Mycobacteria Growth Indicator Tube (BACTEC MGIT 960), and the Versa TREK system [90].

\section{Serology or antibody detection test (humoral immune response)}

Diagnosis based on an antibody is the most widely used approach for detecting TB in wild boar and pigs because of the maintenance of antibodies during transportation, storage, and handling, and the fact that the protocol can be standardized in different laboratories [93-97]. A widely used antigen is the isolated PPD from M. bovis (bovine PPD) $[95,98,99]$. However, new research has focused on improving its specificity through the use of different antigens, for example, MPB83, as described by García-Bocanegra [100,101], MPB70 [102], or CFP10/ESAT-6 [103,104]. Responses to MPB83 were identified at an earlier stage during experimental infections, with antibody responses arising 3-4 weeks after infection [105-108]. Moreover, antibodies directed at ESAT-6 and MPB70 were observed at 12 weeks [109] and 20 months after experimental infection, respectively, as reported by Fifis [110]. Hence, the highest and more rapid response to MPB83 protein proves that it is a better protein for use in producing diagnostic antigens for serological tests [55]. Several novel diagnostic tests explicitly designed to detect MTBC infection in wildlife have been established, such as the DPP (dual-path platform) WTB (MPB83, MPB70), DPP VetTB (MPB83, ESAT6, CFP-10) [99], TB ELISA-VK ${ }^{\circledR}$ kit test (bPPD) [111], INgezim TB CROM Ab, INgezim Tuberculosis DR (based on MPB83), INgezim TB Porcine (based on MPB83 and MPB70) [112], and P22 ELISA (MPB70, MPB83, ESAT-6, CFP-10) [104,113].

\section{Molecular Diagnosis}

\section{Multiplex PCR in the diagnosis of MTBC}

Multiplex PCR methods produce a higher rate of the detection of MTBC. These techniques amplify two or more target genes in a reaction simultaneously [114,115]. A single target could end in a false-negative result, as a number of the targeted genes are not present in some MTBC strains $[115,116]$. The most efficient approach is one based on primers that amplify segments of the IS6110 element, especially targeting the $123 \mathrm{bp}$ and $245 \mathrm{bp}$ fragments. 
Insertion sequences (IS) are mobile genetic elements that constitute a form of repetitive DNA in bacterial genomes. Insertion IS6110 is an IS of $1361 \mathrm{bp}$ that is not present in mycobacteria other than members of the MTBC [117]. Another PCR that produces excellent recognition of $M$. bovis isolates relies on the amplification of a $500 \mathrm{bp}$ DNA segment, especially targeted for the $123 \mathrm{bp}$ and 245 bp fragments inside the RvD 1Rv2031c genomic sequence $[118,119]$. Multiplex PCR has the advantage of being fast and accurate and can differentiate $M$. bovis from other members of MTBC by amplification of two DNA fragments $[115,116,120]$.

\section{Digital PCR (dPCR) in the diagnosis of MTBC}

Digital PCR (dPCR) was more accurate [121] while some reported that it was not susceptible to inhibitors [122] compared with real-time quantitative PCR (qPCR) and does not require a calibration curve needed to produce a qPCR copy number [123]. The high precision of PCR and theoretical accuracy have led to its use to measure reference materials $[124,125]$ and to enable other molecular methods to be optimized [126]. Because of the lipid-rich cell wall and large GC-rich bacterial genome (4.4 MB) of MTBC members, makes diagnosis using other molecular methods difficult [127]. The dPCR was chosen to analyze this problematic genome and to quantify plasmid and MTBC gDNA with different PCR master-mixes, pairs of primers, and platforms of dPCR [128].

\section{DNA markers for the detection of MTBC}

Some important DNA markers used in differentiating MTBC from non-tuberculous mycobacteria (NTM) in the diagnosis of TB include rrs (16S rRNA), ITS (16S-23S rRNA), IS6110, groEL2 (hsp65), dnaJ, fbpA (32 kDa protein), MPT64 (MPB64), devR, PPE24 (KS4), and lepA [129].

rrs (16S rRNA)

Studies have revealed that the 16S rRNA sequence can be used for the detection of mycobacteria, requiring fewer than 10,000 bacteria [130]. For species that are not easily characterized using normal biochemical methods, 16S rRNA can be used for identification, leading to the recognition of new species [131]. Nucleic acid amplification methods such as PCR, real-time PCR, and reverse crossblot hybridization PCR of the 16S rRNA gene can be used to distinguish between MTBC and NTM members [132]. However, the use of the 16S rRNA gene alone is insufficient to differentiate MTBC and NTM groups because members of MTBC have $99.9 \%$ nucleotide resemblance and contain similar 16S rRNA sequences, and there is little difference genetically among NTM species $[133,134]$.

\section{ITS (16S-23S rRNA)}

PCR amplification of the 16S-23S rRNA internal transcribed spacer (ITS) is used to recognize the genus Mycobacterium, which is applied to distinguish between MTBC and NTM based on the specific primer sequence [135]. This biomarker ITS 16S-23S rRNA is a spacer that distinguishes $16 \mathrm{~S}$ and $23 S \mathrm{r} R N A$ genes. Its size ranges from 270 to $360 \mathrm{bp}$ among species, with greater sequence variation than the 16S rRNA [136]. ITS sequencing has a better ability to detect variation in species [137]. When the IS6110 gene is lacking, sequence analysis of ITS helps in identifying MTBC members [138]. Slow growers have shorter ITS than fast growers, with its length correlating with the growth rate. The ITS sequence is found among MTBC, with the same sequence existing among $M$. tuberculosis, M. bovis, M. bovis BCG, M. africanum, and M. microti [139].

\section{IS6110}

Insertion sequences (ISs) are short mobile genetic DNA elements encoding proteins responsible for the transposition activity, which permit them to spread within the genome. In the bacterial genome, the insertion sequence causes deletions, duplications, and rearrangements due to changes in the genomic plasticity of mycobacterial species [140]. IS6110 is the most available and easily characterized insertion element, which is found mainly in MTBC; it is used to distinguish MTBC from other mycobacteria. Several copies of this element are available at different positions in the genome, which facilitates better strain genotyping [141]. IS6110-restriction fragment length polymorphism (RFLP) has been widely used for epidemiological research on TB and has high discriminatory power, but is not suitable for species with less number of IS6110 copies [141]. IS6110 PCR and realtime PCR have shown high sensitivity (71-87.9\%) and specificity (95-98\%) compared with culture and acidfast bacilli [142].

\section{GroEL2 (hsp65)}

The identification of all mycobacterial strains is achieved using the hsp 65 gene, which encodes a heat shock protein [143]. hsp65-PCR-RFLP can distinguish between mycobacteria and NTM [144], with a sensitivity of $100 \%$ and specificity of $93.1 \%$, in contrast to culture and microscopy methods [145]. hsp65 can be applied for specific recognition of NTM and can identify $M$. avium complex and $M$. intracellulare [146]. hsp65 sequencing analysis is more accurate (88.9\%) for identifying NTM than 16S rRNA (75.9\%) [134].

dnaj

The dnaj gene encodes a cold-shock protein, which is a genus-specific gene that is amplified from almost all mycobacteria [147]. MTBC has similar dnaj sequences, while NTM has nucleotide substitutions at positions 1415 (A-C), 1417b (G-T/A/C), and 1442 (C-A), which are distinguished by the application of dnaj-PCR-RFLP [148] GENECUBE (Toyobo, Japan). This is an automated gene analyzer based on real-time PCR that targets the dnaj gene to detect the presence of MTBC and MAC [149]. When 56 species of mycobacteria were sequenced for $d n a j, 16 \mathrm{~S}$ rRNA, 
and hsp65 genes, mean sequence similarity levels were $80.4 \%, 96.6 \%$, and $91.1 \%$, respectively. This proved that dnaj has higher discriminatory power than 16S rRNA and hsp 65 genes and is useful for differentiating NTM [150].

\section{fbpA (32 kDa protein)}

$f b p A$ is a secreted protein that is present in most MTBC strains but absent in non-MTBC strains [151]. Sequencing analysis has revealed that the $f b p A$ gene is similar between MTBC groups, but has distinct sequences within MTBC species, such as M. kansasii, M. gastri, M. gardone, and M. malmoense [152]. This $f b p A$ gene has better discriminatory power than the hsp65 gene for identifying different NTM species [153].

\section{MPT64 (MPB64)}

The MPB64 gene is generally found in members of the MTBC and is used as an indicator in the diagnosis of paratuberculosis (PTB), TB meningitis, and extrapulmonary TB [154]. PCR using MPB64, has been shown to have sensitivity of $88 \%$ and specificity of $100 \%$ [155]. It can be used to diagnose TB in sputum, cerebrospinal fluid (CSF), ascitic fluid, and urine samples, but tends to give false-positive results in blood samples [156]. Studies have shown that MPB64 is complementary to IS6110 PCR and has the capacity to decrease false-negative results in strains lacking the IS6110 element [157]. Gene mutation is the major cause of false-negative results [158].

DevR

$\operatorname{dev} R$ encodes the cytoplasmic response regulator $\operatorname{DevR}$, which works together with the membrane-bound sensor kinase DevS to form DevRS. During latent infection in the host, DevRS is responsible for adaptation and dormancy [159]. Despite reports that shorter fragments of the $\operatorname{dev} R$ gene significantly increased the sensitivity of TB diagnosis [160], the sensitivity of $\operatorname{dev} R$ PCR assay is lower than that of MPB64 and IS6110 [161].

\section{PPE24 (KS4)}

Some MTBC genes that have been less used for biomarker include the KS4 fragment of the Rv1753c gene, encoding the protein PPE. It has sensitivity of $98 \%$ and specificity of $98 \%$ in identifying MTBC, and cross-reacts with $M$. fortuitum and M. xenopi [129].

LepA

The Rv2404c gene encodes an elongation factor that is required for protein synthesis in MTBC members, but not in NTM [162]. It has been used as a target for internal amplification control to develop a realtime PCR assay detecting MTBC [163].

\section{Genotyping Techniques used in MTBC Diagnosis}

Molecular typing uses genetic markers to search for sources of outbreaks, to detect the epidemic or pandemic spread of particular strains, or to reconstruct the evolutionary trends of a specific group of bacteria. The majority of the genotyping methods were developed in the 1990s. At this time, efforts were made toward standardizing typing protocols to increase the quality of epidemiological research [164]. Genotyping is divided into two methods: The whole-genome techniques and partial-genome typing of MTBC [165]. The whole-genome techniques have the benefits of using all of the organism's available genetic information. Knowledge of the mutation rate is a critical factor determining the effectiveness of different genotyping methods. The mutation rate describes the frequency at which molecular fingerprint patterns change and is important for appropriate analysis of molecular data for epidemiological or phylogenetic research [166,167]. A higher mutation rate could result in the high estimation of epidemiologically unrelated MTBC, which occurs at hypervariable loci $[90,168]$.

\section{Whole-genome Typing of MTBC}

\section{Restriction endonuclease analysis (REA)}

This technique uses three restriction enzymes, namely, BstEII, $P v u I$ I, and $B c l$ I, for typing $M$. bovis isolates [169] and the joining of DNA strands of whole-genome DNA at specific nucleotide sequences. These restriction endonucleases digest their targets into several smaller segments, which are then differentiated by standard agarose gel electrophoresis. The developed segment patterns are visualized and compared with other isolates, enabling the differentiation of strains. The development of REA enables us to confirm whether domestic animals have become infected on farms or whether the infection was the result of the purchase of an initially diseased animal $[170,171]$. In some countries, this technique is used for epidemiological evaluation [172], but is yet to gain wide acceptance for this because of technical problems and difficulties in interpreting patterns. However, it is applicable to MTBC prevention and control programs.

\section{Pulsed-field gel electrophoresis}

The technique of pulsed-field gel electrophoresis (PFGE) was initiated to bypass the problem of analysis of excessive smaller number of DNA segments produced by REA. The PFGE process utilizes restriction enzymes that provide a smaller number of sections, which are very large, to be differentiated by standard agarose gel electrophoresis; but it is easily resolved using a pulsed electrical field. Initially, this approach was developed for M. tuberculosis isolates [173], but it was later employed for $M$. bovis and $M$. bovis BCG [174,175].

\section{Whole-genome sequencing (WGS)}

Publication of the whole-genome sequences of M. tuberculosis, M. bovis and M. bovis BCG [176-178] is among the major scientific achievements in molecular tuberculosis research. Since its introduction, WGS has been used and has brought changes in genotyping 
by enabling the highest level of discrimination. WGS is a reliable method for forensic transmission and characterization analysis, allowing the assessment of genetic differences over time and the identification of transmission patterns at the individual level [179]. At present, WGS cannot be applied for regular diagnosis because of its cost and the need for a bioinformatic method. However, this ongoing progress is expected to increase our understanding of $M$. bovis infection and its effect on local epidemics.

\section{Whole-genome microarray}

The introduction of whole-genome sequence data for different species of the MTBC has made it possible to apply microarray technology to compare strains, which has been particularly used to sequence reference strains [180]. The major objective of this technique is to perform comparative genomic hybridization, referred to as comparative genomics (DNA microarray), and for the comparison of gene expression, known as transcriptomics or expression profiling (RNA microarray). The designs for these different approaches are the same and do not depend on the initial products (DNA or RNA). PCR products that are open reading frame (ORF) genes of reference strains are applied on a solid material (e.g., glass slides), then the amplification of PCR products for DNA and reverse transcriptase for RNA is performed, followed by the application of fluorescent dyes that are then hybridized on the slides [181]. Subsequently, the spots produced are visualized with a fluorescence reader and analyzed using the software. Comparative genomics clarifies discrepancies among groups of MTBC, and the application of whole genomes has shed light on the pathogenesis, host adaptation [182], and virulence of different $M$. bovis strains [183]. It also helps to identify chromosomal polymorphisms as genetic markers for clonal complexes [184-186]. However, this method can be used only for research studies, rather than for regular diagnosis.

\section{Partial-genome Typing of MTBC}

\section{Restriction fragment length polymorphism}

Restriction fragment length polymorphism (RFLP) analysis utilizes the restriction enzyme $P v u \mathrm{II}$ or AluI, followed by southern blotting and gel electrophoresis of the fragmented isolated DNA onto a nitrocellulose or nylon filter [115]. RFLP based on IS6110 is the genotyping method commonly applied for M. tuberculosis strains, which contain up to 20 copies of this IS [187]. However, this method is not easy to apply in different laboratories [188]. This technique also lacks discrimination for low-copy-number strains such as M. bovis; it is not frequently used for typing or routine diagnosis [164,189-191].

\section{Spoligotyping}

Spoligotyping, also known as spacer oligonucleotide typing, is a rapid and robust technique that enables MTBC isolates to be typed at high throughput, with no need for DNA purification [192]. In a previous study [193], researchers were able to identify a clustered regularly interspaced palindromic repeat (CRISPR) region peculiar to the MTBC known as the direct repeat (DR) region. It is composed of multiple 36 bp DRs interspersed by unique sequences referred to as spacers, of 25-41 bp in length [194]; a DR and its adjacent spacer are called a direct variant repeat (DVR). The strains differ in terms of the number of DVRs; the presence or absence of the spacers is used for strain typing. While 104 spacer sequences are found in the DR region, not all exhibit sufficient polymorphisms that are important for strain typing [194,195]. The appropriate spoligotyping mehods involved the use of 43 spacers [192]. Two primers are utilized to target individual DRs and amplify the entire DR region with subsequent hybridization of fragments on a blotting membrane, which is joined by covalent binding to oligonucleotides and visualized through chemiluminescence. The membranes are prepared in the laboratory or obtained commercially from Ocimum Biosolution Ltd. (Hyderabad, India). This reverse line blot hybridization analysis provides results that are simple to save due to translation of the patterns into a binary code ( 0 , absence of spacer; and 1, presence of spacers), and globally approved names for the spoligotype patterns, which are copied from spoligotype websites (http:// www.Mbovis.org; http://www.pasteur-guadeloupe.fr/ tb/bd_myco.html) [196,197].

\section{Variable number tandem repeats}

Variable number tandem repeat (VNTR) typing has focused on genetic loci that are found in the entire genome; these loci contain an enormous amount of data of repeated sequences. Due to various polymorphisms in the copy number of the repeats, the tandem repeats were successfully used to fingerprint bacterial genomes [198]. VNTR typing, also called multilocus variable number tandem repeat analysis (MLVA), has several benefits, such as relatively low cost, simplicity in terms of use, and the production of unambiguous results [199]. VNTR typing relies on the PCR amplification of targeted loci with a particular primer pair and then gel electrophoresis. The application of automatic sequencers to check the correct size of the amplified fragments has been optimized in several research and diagnostic laboratories, enabling automated high-impact genotyping [200]. For the interpretation of results, the application of an allele calling table related to several band sizes that are equivalent to the number of repeats in each locus is indispensable. The earlier VNTR locus found in the M. tuberculosis genome contains about $75 \mathrm{bp}$ tandem repeats situated in the large ORF [201]. It was previously reported [202] that some loci are found in ORFs, for example, QUB11a, QUB18, QUB23, and QUB26. Many loci found within coding regions have repeat sizes that are multiples of three. Several scattered repeats are found in intergenic regions and are known 
to play an important role in the bacterial genome. In a previous study [203], these loci were called mycobacterial interspersed repetitive units (MIRUs), with a size range from 46 to $101 \mathrm{bp}$. VNTR typing of MTBC is also called MIRU-VNTR typing. The number of MIRUs per genome is around 40-50. VNTR typing is useful for epidemiological studies and can be used to recognize multiple infections [204,205].

\section{IS6110 ample printing}

Ample printing uses a polymorphic tandem repeat (MPTR) sequence [206], which is similar to the DR region comprising $10 \mathrm{bp}$ direct repeats separated by $5 \mathrm{bp}$ unique spacers. MPTR was found in atypical mycobacteria and possessed few polymorphisms in the MTBC. Nonetheless, for M. tuberculosis, excellent results have been obtained by applying this approach in combination with IS6110, referred to as IS6110ample printing, which makes use of the gap between IS6110 and copies of MPTR sequences. Because the results of ample printing differ significantly in terms of discrimination and reproducibility, it is not regularly used as a diagnostic technique [207-209].

\section{Random amplified polymorphic deoxyribonucleic acid (RAPD) analysis}

Because of its simplicity, RAPD is usually used for genotyping organisms, as a PCR-based fingerprinting method [210]. It was initially established for the typing of M. tuberculosis isolates, as described previously [211]. However, it is rarely used for M. bovis because of poor results in terms of discrimination ability $[207,212]$. Problems associated with reproducibility have made this method unpopular for the genotyping of mycobacterial species.

\section{Multilocus sequence typing (MLST)}

The primary purpose of MLST is to categorize organisms in terms of the level of neutral sequence diversity [213]. It has been applied to the characterization of organisms of bacterial origin by a technique of sequencing internal fragments of about 450-500 bp of approximately seven housekeeping genes. For each individual gene, differentsequences are allocated specific alleles, with the aim that an isolate with allelic data or sequence type (ST) is gained by joining the alleles at each locus. Housekeeping gene produce differences slowly, which makes them selectively neutral. Incontrast with other bacterial organisms with variation in housekeeping genes, members of MTBC are monomorphic with reduced discrimination levels [214] to improve discrimination, characterization of housekeeping genes such as encoding antigens and antibiotic-resistance genes, and genes targeting the region of insertion is necessary [215].

\section{RD typing}

Region of Deletion (RD) typing is used for the differentiation of species that are members of MTBC. RD9is used to differentiate M. tuberculosis from other members of the MTBC and RD4 which is not found in all of M. bovis isolates. As a result,
RDs were used as PCR targets as a rapid method of species identification; more recently, additional RDs were discovered, namely, RD2seal [216], RD1mic [217], RD1das [218], RD1 mun RD12oryx, and RD1 BCG, to distinguish $M$. pinnipedii, M. microti, M. dassie bacillus, $M$. mungi, $M$. orygis, and $M$. bovis BCG, respectively, from other species [18,20,219]. For PCR application, different methods are used, such as using three primers, involving two flanking and one internal primer [220,221], or four primers, involving two flanking and two internal primer pairs [137], to locate the presence or absence of the RDs. Several applications of PCR to find different RDs have been approved for species differentiation [222,223]. Because of the one-directional evolution of the RDs [224], these markers are beneficial for the emergence of MTBC and to find clonal complexes within the MTBC host-adapted members [185,186].

\section{Single-nucleotide polymorphism (SNP)}

SNP typing is an essential form of genotyping analysis that enables differentiation among members of MTBC, for example, M. bovis [16] and M. caprae [225]. A previous study [163] described a unique $M$. caprae-specific SNP in the $M$. tuberculosis $\mathrm{H} 37 \mathrm{Rv}$ lepA $(R v 2404 c)$ gene, which is particular to bovine and cervidae isolates [162]. Genotyping using SNP serves as an excellent technique for the recognition of specific lineages in M. tuberculosis [226,227] and M. bovis $[228,229]$. A commercial DNA strip uses the RD1 deletion for the identification of $M$. bovis BCG and differentiation of MTBC species [230], which makes it a useful tool for the diagnosis of tuberculosis in different wild animals [34-36].

\section{Conclusion}

Tuberculosis remains a global threat at the livestock - wildlife - human interface which require different diagnostic approach in the disease detection, prevention and control strategies. Each of these diagnostic methods has its own merits and demerits in terms of application and efficiency. The antemortem diagnosis detected CMI responses using the SITT, SCITT, and gamma interferon test (IFN-y). The skin test requires animals to be handled twice, which is dangerous, especially for some wildlife, and the test cannot be repeated for about 90 days due to immunological sensitization to the PPD antigens. The higher sensitivity of the IFN- $\gamma$ test relative to the skin test is because the IFN- $\gamma$ test detects TB disease in animals as early as 14 days after infection and 60-120 days faster than the SCITT test. For postmortem diagnosis, direct smears are the fastest, cheapest, and simplest way to detect acid-fast MTBC. For this reason, a direct smear of tissue samples can be stained following the ZiehlNeelsen technique to provide a presumptive identification of MTBC. Histopathological techniques have high specificity and the advantage of producing results within a few days. A correlation was found between the results obatained using histopathology and culture 
methods. Serology or antibody detection is the most widely used approach for the detection of TB in wild animals because of the maintenance of antibodies during transportation, storage, and handling, the ability to standardize the protocol in different laboratories, and the fact that the results are obtained within a short period of time. One disadvantage of antibody detection is that humoral responses to infection occur at the later stage of the disease. Bacterial culture remains the gold standard diagnostic method for $\mathrm{MTBC}$, but requires several weeks to obtain positive results due to the extremely fastidious growth of tuberculous mycobacteria. It is used for species differentiation and has high sensitivity and specificity. Molecular diagnostic techniques of MTBC have advantages over conventional methods due to their sensitivity and specificity, being less complicated, less time-consuming, but expensive and not cost-effective compared with conventional methods for the early confirmation of the diagnosis of TB in both humans and animals. Molecular genotyping methods are used to differentiate between MTBC and NTM, and for species differentiation, which are not possible by the conventional approach. The combination of antemortem, postmortem, and molecular diagnostic techniques is the best option for controlling and preventing TB in both humans and wild animals.

\section{Authors' Contributions}

YML and AC conceived and designed the review outlines, collected the data and analyzed the data. PTO, SO, MM, SZR, SJ, and FFAJ analyzed the data and supervised the writing of the manuscripts. All authors have read and approved the final manuscript.

\section{Acknowledgments}

The authors wish to show appreciation to the Ministry of Higher Education of Malaysia (FRGS/1/2019/WAB01/UPM/02/35) and Universiti Putra Malaysia (GP-IPM/2019/9673500) for providing the research grant to conduct the wildlife tuberculosis research.

\section{Competing Interests} interests.

The authors declare that they have no competing

\section{Publisher's Note}

Veterinary World remains neutral with regard to jurisdictional claims in published institutional affiliation.

\section{References}

1. Poirier, V., Rivière, J., Bouveret, A., Gardon, S. and Dufour, B. (2019) Cost-effectiveness assessment of three components of the bovine tuberculosis surveillance system by intradermal tuberculin testing in French cattle farms by a scenario tree approach. Prev. Vet. Med., 166: 93-109.

2. Cowie, C.E., Gortázar, C., White, P.C., Hutchings, M.R. and Vicente, J. (2015) Stakeholder opinions on the practicality of management interventions to control bovine tuberculosis. Vet. J., 204(2): 179-185.
3. Gortazar, C., Diez-Delgado, I., Barasona, J.A., Vicente, J., De La Fuente, J. and Boadella, M. (2015) The wild side of disease control at the wildlife-livestock-human interface: A review. Front. Vet. Sci., 1: 27.

4. Meiring, C., van Helden, P.D. and Goosen, W.J. (2018) TB control in humans and animals in South Africa: A perspective on problems and successes. Front. Vet. Sci., 5: 298.

5. World Health Organization. (2015) Undefined Global Tuberculosis Report. World Health Organization, Geneva. p1-204. https://apps.who.int/iris/handle/10665/191102. Retrieved on 20-02-2020.

6. Thoen CO, Kaplan B, Thoen TC, Gilsdorf MJ. and Shere JA. (2016) Zoonotic tuberculosis. A comprehensive one healthapproach. Medicina (Buenos Aires), 76(3): 159-165.

7. World Health Organization. (2017) Tuberculosis Report 2017 Global. World Health Organization, Geneva. https://www.who.int/tb/publications/global_report/ MainText_13Nov2017.pdf?ua=1. Retrieved on 20-02-2020.

8. Good, M., Bakker, D., Duignan, A. and Collins, D.M. (2018) The history of in vivo tuberculin testing in bovines: Tuberculosis, a "One Health" issue. Front. Vet. Sci., 5: 59.

9. Kohl, T.A., Utpatel, C., Schleusener, V., De Filippo, M.R., Beckert, P., Cirillo, D.M. and Niemann, S. (2018) MTBseq: A comprehensive pipeline for whole genome sequence analysis of Mycobacterium tuberculosis complex isolates. PeerJ, 6: e5895.

10. World Health Organization. (2019) Tuberculosis Report 2019. World Health Organization, Geneva. https://www. who.int/tb/publications/global_report/en/. Retrieved on 20-02-2020.

11. Orgeur, M., \& Brosch, R. (2018). Evolution of virulence in the Mycobacterium tuberculosis complex. Curr. Opin. Microbiol., 41, 68-75.

12. Reed, G.B. (1957) Genus Mycobacterium (species affecting warm-blooded animals except those causing leprosy) In: Bergey's Manual of Determinative Bacteriology. $7^{\text {th }}$ ed. The Williams and Wilkins Co., Baltimore. p703-704.

13. Castets, M., Rist, N. and Boisvert, H. (1969) The African variety of the human tubercle bacillus. Med. Afr. Black, 16(1): 321-322.

14. Karlson, A.G. and Lessel, E.F. (1971) Mycobacterium bovis nom. nov. Evol. Microbiol. Int. J. Syst., 21(2): 216-216.

15. Van Soolingen, D., Hoogenboezem, T., De Haas, P.E., Hermans, P.W., Koedam, M.A., Teppema, K.S., Brennan, P.J., Besra, G.S., Portaels, F., Top, J. and Schouls, L.M. (1997) A novel pathogenic taxon of the Mycobacterium tuberculosis complex, Canetti: Characterization of an exceptional isolate from Africa. Int. J. Syst. Bacteriol., 47(4): 1236-1245.

16. Aranaz, A., Cousins, D., Mateos, A. and Domínguez, L. (2003) Elevation of Mycobacterium tuberculosis subsp. caprae Aranaz et al. 1999 to species rank as Mycobacterium caprae comb. nov., sp. nov. Int. J. Syst. Evol. Microbiol., 53(6): 1785-1789.

17. Cousins, D.V., Bastida, R., Cataldi, A., Qous, V., Redrobe, S., Dow, S., Duignan, P., Murray, A., Dupont, C., Ahmed, N. and Collins, D.M. (2003) Tuberculosis in seals caused by a novel member of the Mycobacterium tuberculosis complex: Mycobacterium pinnipedii sp. nov. Int. J. Syst. Evol. Microbiol., 53(5):1305-1317.

18. Alexander, K.A., Laver, P.N., Michel, A.L., Williams, M., van Helden, P.D., Warren, R.M. and van Pittius, N.C.G. (2010) Novel Mycobacterium tuberculosis complex pathogen, M. mungi. Emerg. Infect. Dis., 16(8): 1296-1299.

19. Lomme, J.R., Thoen, C.O., Himes, E.M., Vinson, J.W. and King, R.E. (1976) Mycobacterium tuberculosis infection in two East African oryxes. J. Am. Vet. Med. Assoc., 169(9): 912-914.

20. van Ingen, J., Rahim, Z., Mulder, A., Boeree, M.J., Simeone, R., Brosch, R. and van Soolingen, D. (2012) Characterization of Mycobacterium orygis as $M$. tuberculosis complex subspecies. Emerg. Infect. Dis., 18(4): 653-655.

21. Wagner, J.C., Buchanan, G., Bokkenheuser, V. and 
Leviseur, S. (1958) An acid-fast bacillus isolated from the lungs of the cape hyrax, Procavia capensis (Pallas) Nature, 181(4604): 284-285.

22. Rodriguez-Campos, S., Smith, N.H., Boniotti, M.B. and Aranaz, A. (2014) Overview and phylogeny of Mycobacterium tuberculosis complex organisms: Implications for diagnostics and legislation of bovine tuberculosis. Res. Vet. Sci., 97(Suppl): S5-S19.

23. Bailey, S.S., Crawshaw, T.R., Smith, N.H. and Palgrave, C.J. (2013) Mycobacterium bovis infection in domestic pigs in Great Britain. Vet. J., 198(2): 391-397.

24. Matos, A.C., Figueira, L., Martins, M.H., Matos, M., Morais, M., Dias, A.P., Pinto, M.L. and Coelho, A.C. (2014) Disseminated Mycobacterium bovis Infection in red foxes (Vulpes vulpes) with cerebral involvement found in Portugal. Vector Borne Zoonotic. Dis., 14(7): 531-533.

25. Gortazar, C., Delahay, R.J., Mcdonald, R.A., Boadella, M., Wilson, G.J., Gavier-Widen, D. and Acevedo, P. (2012) The status of tuberculosis in European wild mammals. Mammal Rev., 42(3): 193-206.

26. Barnett, J.E.F., Booth, P., Brewer, J.I., Chanter, J., Cooper, T., Crawshaw, T., Davison, N.J., Greenwood, A., Riley, P., Smith, N.H. and Wessels, M. (2013) Mycobacterium bovis infection in a grey seal pup (Halichoerus grypus) Vet. Rec., 173(7): 168-168.

27. Díez-Delgado, I., Sevilla, I.A., Romero, B., Tanner, E., Barasona, J.A., White, A.R., Lurz, P.W., Boots, M., de la Fuente, J., Dominguez, L. and Vicente, J. (2018) Impact of piglet oral vaccination against tuberculosis in endemic free-ranging wild boar populations. Prev. Vet. Med., 155: 11-20.

28. Gormley, E. and Corner, L.A. (2018) Wild animal tuberculosis: Stakeholder value systems and management of disease. Front. Vet. Sci., 5: 327.

29. Iovane, V., Ferrara, G., Petruccelli, A., Veneziano, V., D'Alessio, N., Ciarcia, R., Fioretti, A., Pagnini, U. and Montagnaro, S. (2020) Prevalence of serum antibodies against the Mycobacterium tuberculosis complex in wild boar in Campania Region, Italy. Eur. J. Wildl. Res., 66(1): 20.

30. Jones, G.J., Steinbach, S., Sevilla, I.A., Garrido, J.M., Juste, R. and Vordermeier, H.M. (2016) Oral vaccination of cattle with heat inactivated Mycobacterium bovis does not compromise bovine TB diagnostic tests. Vet. Immunol. Immunopathol, 182: 85-88

31. Matos, A.C., Andrade, S., Figueira, L., Matos, M., Pires, M.A., Coelho, A.C. and Pinto, M.L. (2016) Mesenteric lymph node granulomatous lesions in naturally infected wild boar (Sus scrofa) in Portugal histological, immunohistochemical and molecular aspects. Vet. Immunol. Immunopathol., 173: 21-26.

32. Michel, A.L., Müller, B. and Van Helden, P.D. (2010) Mycobacterium bovis at the animal human interface: A problem, or not? Vet. Microbiol., 140(3-4): 371-381.

33. Viljoen, I.M., Van Helden, P.D. and Millar, R.P. (2015) Mycobacterium bovis infection in the lion (Panthera leo): Current knowledge, conundrums and research challenges. Vet. Microbiol., 177(3-4): 252-260.

34. De Vos, V., Bengis, R.G., Kriek, N.P.J., Keet, D.F., Raath, J.P., Huchzermeyer, H.F. and Michel, A.L. (2001) The epidemiology of tuberculosis in free-ranging African buffalo (Syncerus caffer) in the Kruger National Park, South Africa. Onderstepoort J. Vet. Res., 68(2): 119-130.

35. Keet, D.F., Michel, A.L., Bengis, R.G., Becker, P., Van Dyk, D.S., Van Vuuren, M., Rutten, V.P.M. and Penzhorn, B.L. (2010) Intradermal tuberculin testing of wild African lions (Panthera leo) naturally exposed to infection with Mycobacterium bovis. Vet. Microbiol., 144(3-4): 384-391.

36. Sichewo, P. R., Hlokwe, T. M., Etter, E. M., \& Michel, A. L. (2020). Tracing cross species transmission of Mycobacterium bovis at the wildlife/livestock interface in South Africa. BMC Microbiol., 20: 49.

37. Thapa, J., Nakajima, C., Gairhe, K.P., Maharjan, B., Paudel, S., Shah, Y., Mikota, S.K., Kaufman, G.E.,
McCauley, D., Tsubota, T. and Gordon, S.V. (2017) Wildlife tuberculosis: An emerging threat for conservation in South Asia. In: Global Exposition of Wildlife Management. BoDBooks on Demand, Norderstedt, Germany. p73.

38. Ong, B.L., Ngeow, Y.F., Razak, M.A., Yakubu, Y., Zakaria, Z., Mutalib, A.R., Hassan, L., Ng, H.F. and Verasahib, K. (2013) Tuberculosis in captive Asian elephants (Elephas maximus) in Peninsular Malaysia. Epidemiol. Infect., 141(7): 1481-1487.

39. Yakubu, Y., Ong, B.L., Zakaria, Z., Hassan, L., Mutalib, A.R., Ngeow, Y.F., Verasahib, K. and Razak, M.F.A. (2016) Evidence and potential risk factors of tuberculosis among captive Asian elephants and wildlife staff in Peninsular Malaysia. Prev. Vet. Med., 125: 147-153.

40. Angkawanish, T., Wajjwalku, W. and Sirimalaisuwan, A. (2010) Mycobacterium tuberculosis infection of domesticated Asian elephants, Thailand. Emerg. Infect. Dis., 16(12): 1949-1951.

41. Byrne, A.W., Graham, J., Brown, C., Donaghy, A., Guelbenzu-Gonzalo, M., McNair, J., Skuce, R., Allen, A. and McDowell, S. (2017) Bovine tuberculosis visible lesions in cattle culled during herd breakdowns: The effects of individual characteristics, trade movement and co-infection. BMC Vet. Res., 13(1): 400.

42. O'Hagan, M.J.H., Courcier, E.A., Drewe, J.A., Gordon, A.W., McNair, J. and Abernethy, D.A. (2015) Risk factors for visible lesions or positive laboratory tests in bovine tuberculosis reactor cattle in Northern Ireland. Prev. Vet. Med., 120(3-4): 283-290.

43. Drewe, J.A., Dean, G.S., Michel, A.L. and Pearce, G.P. (2009) Accuracy of three diagnostic tests for determining Mycobacterium bovis infection status in live-sampled wild meerkats (Suricata suricatta) J. Vet. Diagn. Invest., 21(1): 31-39.

44. Corner, L.A. (2006) The role of wild animal populations in the epidemiology of tuberculosis in domestic animals: How to assess the risk. Vet. Microbiol., 112(2-4): 303-312.

45. Ghodbane, R., Medie, F.M., Lepidi, H., Nappez, C. and Drancourt, M. (2014) Long-term survival of tuberculosis complex mycobacteria in soil. Microbiol., 160(3): 496-501.

46. Morris, R.S., Pfeiffer, D.U. and Jackson, R. (1994) The epidemiology of Mycobacterium bovis infections. Vet. Microbiol., 40(1-2): 153-177.

47. Martín-Hernando, M.P., Höfle, U., Vicente, J., Ruiz-Fons, F., Vidal, D., Barral, M., Garrido, J.M., de la Fuente, J. and Gortazar, C. (2007) Lesions associated with Mycobacterium tuberculosis complex infection in the European wild boar. Tuberculosis (Edinb), 87(4): 360-367.

48. Martín-Hernando, M.P., Torres, M.J., Aznar, J., Negro, J.J., Gandía, A. and Gortázar, C. (2010) Distribution of lesions in red and fallow deer naturally infected with Mycobacterium bovis. J. Comp. Pathol., 142(1): 43-50.

49. Vicente, J., Barasona, J.A., Acevedo, P., Ruiz-Fons, J.F., Boadella, M., Diez-Delgado, I., Beltran-Beck, B., GonzálezBarrio, D., Queirós, J., Montoro, V. and de la Fuente, J. (2013) Temporal trend of tuberculosis in wild ungulates from Mediterranean Sea pain. Transbound. Emerg. Dis., 60(Suppl 1): 92-103.

50. Palmer, M.V., Waters, W.R. and Whipple, D.L. (2004) Investigation of the transmission of Mycobacterium bovis from deer to cattle through indirect contact. Am. J. Vet. Res., 65(11): 1483-1489.

51. Boehm, M., Hutchings, M.R. and White, P.C. (2009) Contact networks in a wildlife-livestock host community: Identifying high-risk individuals in the transmission of bovine TB among badgers and cattle. PLoS One, 4(4): e5016.

52. Kukielka, E., Barasona, J.A., Cowie, C.E., Drewe, J.A., Gortazar, C., Cotarelo, I. and Vicente, J. (2013) Spatial and temporal interactions between livestock and wildlife in South Central Spain assessed by camera traps. Prev. Vet. Med., 112(3-4): 213-221. 
53. Barasona, J.A., Mulero-Pázmány, M., Acevedo, P., Negro, J.J., Torres, M.J., Gortázar, C. and Vicente, J. (2014) Unmanned aircraft systems for studying spatial abundance of ungulates: Relevance to spatial epidemiology. PLoS One, 9(12): e115608.

54. Cowie, C.E., Beck, B.B., Gortazar, C., Vicente, J., Hutchings, M.R., Moran, D. and White, P.C. (2014) Risk factors for the detected presence of Mycobacterium bovis in cattle in South Central Spain. Eur. J. Wildl. Res., 60(1): 113-123.

55. Bezos, J., Casal, C., Romero, B., Schroeder, B., Hardegger, R., Raeber, A.J., López, L., Rueda, P. and Domínguez, L. (2014) Current ante-mortem techniques for diagnosis of bovine tuberculosis. Res. Vet. Sci., 97(Suppl): S44-S52.

56. Goodchild, A.V., Downs, S.H., Upton, P., Wood, J.L.N. and De La Rua-Domenech, R. (2015) Specificity of the comparative skin test for bovine tuberculosis in Great Britain. Vet. Rec., 177(10): 258.

57. Lahuerta-Marin, A., Milne, M.G., McNair, J., Skuce, R.A., McBride, S.H., Menzies, F.D., McDowell, S.J.W., Byrne, A.W., Handel, I.G. and Bronsvoort, B.D.C. (2018) Bayesian latent class estimation of sensitivity and specificity parameters of diagnostic tests for bovine tuberculosis in chronically infected herds in Northern Ireland. Vet. J., 238: 15-21.

58. Byrne, A.W., Graham, J., Brown, C., Donaghy, A., Guelbenzu-Gonzalo, M., McNair, J., Skuce, R.A., Allen, A. and McDowell, S.W. (2018) Modelling the variation in skin-test tuberculin reactions, post-mortem lesion counts and case pathology in tuberculosis-exposed cattle: Effects of animal characteristics, histories and co-infection. Transbound. Emerg. Dis., 65(3): 844-858.

59. Miller, M.A., Gortazar, C., Roos, E.O., Risalde, M.A., Johnathan-Lee, A., Sridhara, A.A. and Lyashchenko, K.P. (2019) Serological reactivity to MPB83 and CFP10/ESAT-6 antigens in three suid hosts of Mycobacterium bovis infection. Vet. Microbiol., 235: 285-288.

60. Nunez-Garcia, J., Downs, S.H., Parry, J.E., Abernethy, D.A., Broughan, J.M., Cameron, A.R., Cook, A.J., de la RuaDomenech, R., Goodchild, A.V., Gunn, J. and More, S.J. (2018) Meta-analyses of the sensitivity and specificity of ante-mortem and post-mortem diagnostic tests for bovine tuberculosis in the UK and Ireland. Prev. Vet. Med., 153: 94-107.

61. Clegg, T.A., Doyle, M., Ryan, E., More, S.J. and Gormley, E. (2019) Characteristics of Mycobacterium bovis infected herds tested with the interferon-gamma assay. Prev. Vet. Med., 168: 52-59.

62. Downs, S.H., Parry, J.E., Upton, P.A., Broughan, J.M., Goodchild, A.V., Nunez-Garcia, J., Greiner, M., Abernethy, D.A., Cameron, A.R., Cook, A.J. and de la Rua-Domenech, R. (2018) Methodology and preliminary results of a systematic literature review of ante-mortem and post-mortem diagnostic tests for bovine tuberculosis. Prev. Vet. Med., 153: 117-126.

63. Conlan, A.J., McKinley, T.J., Karolemeas, K., Pollock, E.B., Goodchild, A.V., Mitchell, A.P., Birch, C.P., Clifton-Hadley, R.S. and Wood, J.L. (2012) Estimating the hidden burden of bovine tuberculosis in Great Britain. PLoS Comput. Biol., 8(10): e1002730.

64. Gallagher, M.J., Higgins, I.M., Clegg, T.A., Williams, D.H. and More, S.J. (2013) Comparison of bovine tuberculosis recurrence in Irish herds between 1998 and 2008. Prev. Vet. Med., 111(3-4): 237-244.

65. Brooks-Pollock, E., Roberts, G.O. and Keeling, M.J. (2014) A dynamic model of bovine tuberculosis spread and control in Great Britain. Nature, 511(7508): 228-231.

66. Schiller, I., Oesch, B., Vordermeier, H.M., Palmer, M.V., Harris, B.N., Orloski, K.A., Buddle, B.M., Thacker, T.C., Lyashchenko, K.P. and Waters, W.R. (2010) Bovine tuberculosis: A review of current and emerging diagnostic techniques in view of their relevance for disease control and eradication. Transbound. Emerg. Dis., 57(4): 205-220.

67. Buddle, B.M., De Lisle, G.W., Pfeffer, A. and Aldwell, F.E. (1995) Immunological responses and protection against Mycobacterium bovis in calves vaccinated with a low dose of BCG. Vaccine, 13(12): 1123-1130.

68. Lilenbaum, W., Schettini, J.C., Souza, G.N., Ribeiro, E.R., Moreira, E.C. and Fonseca, L.S. (1999) Comparison between a $\gamma$-IFN Assay and intradermal tuberculin test for the diagnosis of bovine tuberculosis in field trials in Brazil. J. Vet. Med. Ser. B, 46(5): 353-358.

69. Palmer, M.V., Thacker, T.C., Rabideau, M.M., Jones, G.J., Kanipe, C., Vordermeier, H.M. and Waters, W.R. (2020) Biomarkers of cell-mediated immunity to bovine tuberculosis. Vet. Immunol. Immunopathol., 220: Article ID 109988.

70. Goosen, W.J., Miller, M.A., Chegou, N.N., Cooper, D., Warren, R.M., van Helden, P.D. and Parsons, S.D. (2014) Agreement between assays of cell-mediated immunity utilizing Mycobacterium bovis-specific antigens for the diagnosis of tuberculosis in African buffaloes (Syncerus caffer). Vet. Immunol. Immunopathol., 160(1-2): 133-138.

71. Waters, W.R., Palmer, M.V., Stafne, M.R., Bass, K.E., Maggioli, M.F., Thacker, T.C., Linscott, R., Lawrence, J.C., Nelson, J.T., Esfandiari, J. and Greenwald, R. (2015) Effects of serial skin testing with purified protein derivative on the level and quality of antibodies to complex and defined antigens in Mycobacterium bovis-infected cattle. Clin. Vaccine Immunol., 22(6): 641-649.

72. Roupie, V., Alonso-Velasco, E., Van Der Heyden, S., Holbert, S., Duytschaever, L., Berthon, P., Van Dosselaer, I., Van Campe, W., Mostin, L., Biet, F. and Roels, S. (2018) Evaluation of mycobacteria-specific gamma interferon and antibody responses before and after a single intradermal skin test in cattle naturally exposed to M. avium subsp. paratuberculosis and experimentally infected with $M$. bovis. Vet. Immunol. Immunopathol., 196: 35-47.

73. Clarke, C., Cooper, D., Goosen, W.J., McFadyen, R., Warren, R.M., van Helden, P.D., Parsons, S.D.C. and Miller, M.A. (2018) Antigen-specific interferon-gamma release is decreased following the single intradermal comparative cervical skin test in African buffaloes (Syncerus caffer). Vet. Immunol. Immunopathol., 201: 12-15.

74. Jones, G.J., Whelan, A., Clifford, D., Coad, M. and Vordermeier, H.M. (2012) Improved skin test for differential diagnosis of bovine tuberculosis by the addition of Rv3020c-derived peptides. Clin. Vaccine Immunol., 19(4): 620-622.

75. Grange, J.M. (1996) The biology of the genus Mycobacterium. J. Appl. Bacteriol., 81(25): 1S-9S.

76. Collins CH, Grange JM and Yates MD. (1997) Tuberculosis Bacteriology: Organization and Practice. Butterworth Heinemann, Oxford, United Kingdom.

77. Silva, D.A.V., Siconelli, M.J.L., Bürger, K.P. and Keid, L.B. (2018) Comparison between tests for tuberculosis diagnosis in slaughtered bovines. Arq. Inst. Biol, 85(1): 1590.

78. Costello, E. (2004) Laboratory Diagnosis of Tuberculosis, Presentation. Kilkenny Regional Veterinary Laboratory, 18/06/2004, Ireland.

79. World Organisation for Animal Health. (2019) Infection with Mycobacterium tuberculosis Complex, Terrestrial Animal Health Code 28/06/2019. Available from: https:// www.oie.int/fileadmin/home/eng/health_standards/tahc/ current/chapitre_bovine_tuberculosis.pdf. Retrieved on 28-02-2020.

80. Kedir, E., Mamo, G., Legesse, K. and Tassew, A., (2018) Review on advanced diagnostic techniques for Mycobacterium species and its significance to control tuberculosis. J. Bacteriol. Mycol. Open Access, 6(3): 168-177.

81. Santos, N., Geraldes, M., Afonso, A., Almeida, V. and Correia-Neves, M. (2010) Diagnosis of tuberculosis in the wild boar (Sus scrofa): A comparison of methods applicable to hunter-harvested animals. PLoS One, 5(9): e12663.

82. Witkowski, L., Orłowska, B., Rzewuska, M., Czopowicz, M., 
Welz, M., Anusz, K. and Kita, J. (2017) Evidence of low prevalence of mycobacterial lymphadenitis in wild boars (Sus scrofa) in Poland. Acta Vet. Scand., 59(1): 9.

83. Murray, P.R., Baron, E.J., Jorgensen, J.H., Landry, M.L. and Pfaller, M.A. (2007) Manual of Clinical Microbiology. $9^{\text {th }}$ ed. Wiley, Hoboken, New Jersey.

84. Corner, L.A. and Trajstman, A.C. (1988) An evaluation of 1-hexadecylpyridinium chloride as a decontaminant in the primary isolation of Mycobacterium bovis from bovine lesions. Vet. Microbiol., 18(2): 127-134.

85. Corner, L.A.L., Gormley, E. and Pfeiffer, D.U. (2012) Primary isolation of Mycobacterium bovis from bovine tissues: Conditions for maximising the number of positive cultures. Vet. Microbiol., 156(1-2): 162-171.

86. Claxton, P.D., Eamens, G.J. and Mylrea, P.J. (1979) Laboratory diagnosis of bovine tuberculosis. Aust. Vet. J., 55(11): 514-520.

87. Corner, L.A., Trajstman, A.C. and Lund, K. (1995) Determination of the optimum concentration of decontaminants for the primary isolation of Mycobacterium bovis. $N$. Z. Vet. J., 43(4): 129-133.

88. De Lisle, G.W. and Havill, P.F. (1985) Mycobacteria isolated from deer in New Zealand from 1970-1983. N. Z. Vet. J., 33(8): 138-140.

89. Tenover, F.C., Crawford, J.T., Huebner, R.E., Geiter, L.J., Horsburgh, C.R. Jr. and Good, R.C. (1993) The resurgence of tuberculosis: Is your laboratory ready? J. Clin. Microbiol., 31(4): 767.

90. Gormley, E., Corner, L.A.L., Costello, E. and RodriguezCampos, S. (2014) Bacteriological diagnosis and molecular strain typing of Mycobacterium bovis and Mycobacterium caprae. Res. Vet. Sci., 97(Suppl): S30-S43.

91. Issa, M.D.A., Filho, P.M.S., Júnior, A.A.F., Hodon, M.A., Santos, L.C.D., Reis, J.K.P. and Leite, R.C. (2017) Comparative study of Mycobacterium bovis primary isolation methods. Braz. J. Microbiol., 48(1): 139-144.

92. Sattar, A., Zakaria, J.A.Z., Aziz, S.A. and Gabriel, R.P. (2018) Evaluation of six decontamination procedures for isolation of Mycobacterium avium complex from avian feces. PLoS One, 13(8): e0202034.

93. Trost, B., Stuber, T., Surujballi, O., Nelson, J., RobbeAusterman, S., Smith, N.H., Desautels, L., Tikoo, S.K. and Griebel, P. (2016) Investigation of the cause of geographic disparities in IDEXX ELISA sensitivity in serum samples from Mycobacterium bovis-infected cattle. Sci. Rep., 6(1): $1-11$.

94. Casal, C., Infantes, J.A., Risalde, M.A., Díez-Guerrier, A., Domínguez, M., Moreno, I., Romero, B., de Juan, L., Sáez, J.L., Juste, R. and Gortázar, C. (2017) Antibody detection tests improve the sensitivity of tuberculosis diagnosis in cattle. Res. Vet. Sci., 112: 214-221.

95. Infantes-Lorenzo, J.A., Moreno, I., Roy, A., Risalde, M.A., Balseiro, A., de Juan, L., Romero, B., Bezos, J., Puentes, E., Åkerstedt, J. and Tessema, G.T. (2019) Specificity of serological test for detection of tuberculosis in cattle, goats, sheep and pigs under different epidemiological situations. BMC Vet. Res., 15(1): 70.

96. Maas, M., Michel, A.L. and Rutten, V.P. (2013) Facts and dilemmas in diagnosis of tuberculosis in wildlife. Comp. Immunol. Microbiol. Infect. Dis., 36(3): 269-285.

97. Pedersen, K., Miller, R.S., Anderson, T.D., Pabilonia, K.L., Lewis, J.R., Mihalco, R.L., Gortázar, C. and Gidlewski, T. (2017) Limited antibody evidence of exposure to Mycobacterium bovis in feral swine (Sus scrofa) in the USA. J. Wildl. Dis., 53(1): 30-36.

98. Aurtenetxe, O., Barral, M., Vicente, J., de la Fuente, J., Gortázar, C. and Juste, R.A. (2008) Development and validation of an enzyme-linked immunosorbent assay for antibodies against Mycobacterium bovis in European wild boar. BMC Vet. Res., 4(1): 43.

99. Che’Amat, A., González-Barrio, D., Ortiz, J.A., DíezDelgado, I., Boadella, M., Barasona, J.A., Bezos, J.,
Romero, B., Armenteros, J.A., Lyashchenko, K.P., Venteo, A., Rueda, P. and Gortázar, C. (2015) Testing Eurasian wild boar piglets for serum antibodies against Mycobacterium bovis. Prev. Vet. Med., 121(1-2): 93-98.

100. García-Bocanegra, I., de Val, B.P., Arenas-Montes, A., Paniagua, J., Boadella, M., Gortázar, C. and Arenas, A. (2012) Seroprevalence and risk factors associated to Mycobacterium bovis in wild artiodactyl species from southern Spain, 2006-2010. PLoS One, 7(4): 34908.

101. Pérez de Val, B., Napp, S., Velarde, R., Lavín, S., Cervera, Z., Singh, M., Allepuz, A. and Mentaberre, G. (2017) Serological follow-up of tuberculosis in a wild boar population in contact with infected cattle. Transbound. Emerg. Dis., 64(1): 275-283.

102. Cardoso-Toset, F., Luque, I., Carrasco, L., Jurado-Martos, F., Risalde, M.Á., Venteo, Á., Infantes-Lorenzo, J.A., Bezos, J., Rueda, P., Tapia, I. and Gortázar, C. (2017) Evaluation of five serologic assays for bovine tuberculosis surveillance in domestic free-range pigs from Southern Spain. Prev. Vet. Med., 137(A): 101-104.

103. Roos, E.O., Buss, P., de Klerk-Lorist, L.M., Hewlett, J., Hausler, G.A., Rossouw, L., McCall, A.J., Cooper, D., van Helden, P.D., Parsons, S.D. and Miller, M.A. (2016) Test performance of three serological assays for the detection of Mycobacterium bovis infection in common warthogs (Phacochoerus africanus). Vet. Immunol. Immunopathol., 182: 79-84.

104. Thomas, J., Infantes-Lorenzo, J.A., Moreno, I., Cano-Terriza, D., de Juan, L., García-Bocanegra, I., Domínguez, L., Domínguez, M., Gortázar, C. and Risalde, M.A. (2019) Validation of a new serological assay for the identification of Mycobacterium tuberculosis complex-specific antibodies in pigs and wild boar. Prev. Vet. Med., 162: 11-17.

105. O'Loan, C.J., Pollock, J.M., Hanna, J.O.H. and Neill, S.D. (1994) Immunoblot analysis of humoral immune responses to Mycobacterium bovis in experimentally infected cattle: Early recognition of a 26-kilodalton antigen. Clin. Diagn. Lab. Immunol., 1(5): 608-611.

106. Waters, W.R., Palmer, M.V., Thacker, T.C., Bannantine, J.P., Vordermeier, H.M., Hewinson, R.G., Greenwald, R., Esfandiari, J., McNair, J., Pollock, J.M. and Andersen, P. (2006) Early antibody responses to experimental Mycobacterium bovis infection of cattle. Clin. Vaccine Immunol., 13(6): 648-654.

107. Waters, W.R., Whelan, A.O., Lyashchenko, K.P., Greenwald, R., Palmer, M.V., Harris, B.N., Hewinson, R.G. and Vordermeier, H.M. (2010) Immune responses in cattle inoculated with Mycobacterium bovis, Mycobacterium tuberculosis, or Mycobacterium kansasii. Clin. Vaccine Immunol., 17(2): 247-252.

108. Waters, W.R., Buddle, B.M., Vordermeier, H.M., Gormley, E., Palmer, M.V., Thacker, T.C., Bannantine, J.P., Stabel, J.R., Linscott, R., Martel, E. and Milian, F. (2011) Development and evaluation of an enzyme-linked immunosorbent assay for use in the detection of bovine tuberculosis in cattle. Clin. Vaccine Immunol., 18(11): 1882-1888.

109. Lyashchenko, K.P., Pollock, J.M., Colangeli, R. and Gennaro, M.L. (1998) Diversity of antigen recognition by serum antibodies in experimental bovine tuberculosis. Infect. Immun., 66(11): 5344-5349.

110. Fifis, T., Costopoulos, C., Corner, L.A. and Wood, P.R. (1992) Serological reactivity to Mycobacterium bovis protein antigens in cattle. Vet. Microbiol., 30(4): 343-354.

111. Roos, E.O., Olea-Popelka, F., Buss, P., de KlerkLorist, L.M., Cooper, D., van Helden, P.D., Parsons, S.D.C. and Miller, M.A. (2018) Seroprevalence of Mycobacterium bovis infection in warthogs (Phacochoerus africanus) in bovine tuberculosis-endemic regions of South Africa. Transbound. Emerg. Dis., 65(5): 1182-1189.

112. Fresco-Taboada, A., Risalde, M.A., Gortázar, C., Tapia, I., González, I., Venteo, Á., Sanz, A. and Rueda, P. (2019) A 
lateral flow assay for the rapid diagnosis of Mycobacterium bovis infection in wild boar. Transbound. Emerg. Dis., 66(5): 2175-2179

113. Infantes-Lorenzo, J.A., Moreno, I., Risalde, M.Á., Roy, Á., Villar, M., Romero, B., Ibarrola, N., de la Fuente, J., Puentes, E., de Juan, L., Gortázar, C., Bezos, J., Domínguez, L. and Domínguez, M. (2017) Proteomic characterisation of bovine and avian purified protein derivatives and identification of specific antigens for serodiagnosis of bovine tuberculosis. Clin. Proteomics, 14(1): 36.

114. Sharma, K., Sharma, A., Sharma, S.K., Sen, R.K., Dhillon, M.S. and Sharma, M. (2012) Does multiplex polymerase chain reaction increase the diagnostic percentage in osteoarticular tuberculosis? A prospective evaluation of 80 cases. Int. Orthop., 36(2): 255-259.

115. McAdam, R.A., Hermans, P.W.M., Van Soolingen, D., Zainuddin, Z.F., Catty, D., Van Embden, J.D.A. and Dale, J.W. (1990) Characterization of a Mycobacterium tuberculosis insertion sequence belonging to the IS3 family. Mol. Microbiol., 4(9): 1607-1613.

116. Bhembe, N.L., Jaja, I.F., Nwodo, U.U., Okoh, A.I. and Green, E. (2017) Prevalence of tuberculous lymphadenitis in slaughtered cattle in Eastern Cape, South Africa. Int. J. Infect. Dis., 61: 27-37.

117. Filia, G., Leishangthem, G.D., Mahajan, V. and Singh, A. (2016) Detection of Mycobacterium tuberculosis and Mycobacterium bovis in Sahiwal cattle from an organized farm using ante-mortem techniques. Vet. World, 9(4): 383.

118. Ricardo, C.T.C., Vinicius, S.C., Flávia, G.S.S., Carlos, A.C.J., Walter, L., Vânia, M.F.P. and Eduardo, E.S.F. (2015) Detection of Mycobacterium bovis in bovine carcasses by multiplex-PCR. Afr. J. Microbiol. Res., 9(35): 1978-1983.

119. Costa, P., Botelho, A., Couto, I., Viveiros, M. and Inácio, J. (2014) Standing of nucleic acid testing strategies in veterinary diagnosis laboratories to uncover Mycobacterium tuberculosis complex members. Front. Mol. Biosci., 1: 16.

120. Whale, A.S., Huggett, J.F., Cowen, S., Speirs, V., Shaw, J., Ellison, S., Foy, C.A. and Scott, D.J. (2012) Comparison of microfluidic digital PCR and conventional quantitative PCR for measuring copy number variation. Nucleic Acids Res., 40(11): e82-e82.

121. Dingle, T.C., Sedlak, R.H., Cook, L. and Jerome, K.R. (2013) Tolerance of droplet-digital PCR vs real-time quantitative PCR to inhibitory substances. Clin. Chem., 59(11): 1670-1672.

122. Sanders, R., Huggett, J.F., Bushell, C.A., Cowen, S., Scott, D.J. and Foy, C.A. (2011) Evaluation of digital PCR for absolute DNA quantification. Anal. Chem., 83(17): 6474-6484.

123. Corbisier, P., Bhat, S., Partis, L., Xie, V.R. and Emslie, K.R. (2010) Absolute quantification of genetically modified MON810 maize (Zea mays L.) by digital polymerase chain reaction. Anal. Bioanal. Chem., 396(6): 2143-2150.

124. Haynes, R.J., Kline, M.C., Toman, B., Scott, C., Wallace, P., Butler, J.M. and Holden, M.J. (2013) Standard reference material 2366 for measurement of human cytomegalovirus DNA. J. Mol. Diagn., 15(2): 177-185.

125. Devonshire, A.S., O'Sullivan, D.M., Honeyborne, I., Jones, G., Karczmarczyk, M., Pavšič, J., Gutteridge, A., Milavec, M., Mendoza, P., Schimmel, H. and Van Heuverswyn, F. (2016) The use of digital PCR to improve the application of quantitative molecular diagnostic methods for tuberculosis. BMC Infect. Dis., 16(1): 366.

126. Ushio, R., Yamamoto, M., Nakashima, K., Watanabe,H., Nagai, K., Shibata, Y., Tashiro, K., Tsukahara, T., Nagakura, H., Horita, N. and Sato, T. (2016) Digital PCR assay detection of circulating Mycobacterium tuberculosis DNA in pulmonary tuberculosis patient plasma. Tuberculosis, 99: 47-53.

127. Devonshire, A.S., Honeyborne, I., Gutteridge, A., Whale, A.S., Nixon, G., Wilson, P., Jones, G., McHugh, T.D.,
Foy, C.A. and Huggett, J.F. (2015) Highly reproducible absolute quantification of Mycobacterium tuberculosis complex by digital PCR. Anal. Chem., 87(7): 3706-3713.

128. Chin, K.L., Sarmiento, M.E., Norazmi, M.N. and Acosta, A. (2018) DNA markers for tuberculosis diagnosis. Tuberculosis, 113: 139-152.

129. Rogall, T., Flohr, T. and Böttger, E.C. (1990) Differentiation of Mycobacterium species by direct sequencing of amplified DNA. J. Gen. Microbiol., 136(9): 1915-1920.

130. Sun, L., Nie, L., Jiang, Y., Yang, L., Bu, H. and Ye, F. (2016) Rapid and accurate identification of Mycobacterium tuberculosis complex by simultaneous detection of 16S rRNA and IS6110 sequence in FFPE samples. Int. J. Clin. Exp. Pathol., 9(6): 6432-6439.

131. Choi, Y., Hong, S.R., Jeon, B.Y., Wang, H.Y., Lee, G.S., Cho, S.N., Shim, T.S. and Lee, H. (2015) Conventional and real-time PCR targeting $16 \mathrm{~S}$ ribosomal RNA for the detection of Mycobacterium tuberculosis complex. Int. J. Tuberc. Lung Dis., 19(9): 1102-1108.

132. Sinha, P., Gupta, A., Prakash, P., Anupurba, S., Tripathi, R. and Srivastava, G.N. (2016) Differentiation of Mycobacterium tuberculosis complex from non-tubercular mycobacteria by nested multiplex PCR targeting IS6110, MTP40 and 32kD alpha antigen encoding gene fragments. BMC Infect. Dis., 16(1): 123.

133. Baliga, S., Murphy, C., Sharon, L., Shenoy, S., Biranthabail, D., Weltman, H., Miller, S., Ramasamy, R. and Shah, J. (2018) Rapid method for detecting and differentiating Mycobacterium tuberculosis complex and non-tuberculous mycobacteria in sputum by fluorescence in situ hybridization with DNA probes. Int. J. Infect. Dis., 75: 1-7.

134. Park, H., Jang, H., Kim, C., Chung, B., Chang, C.L., Park, S.K. and Song, S. (2000) Detection and identification of mycobacteria by amplification of the internal transcribed spacer regions with genus-and species-specific PCR primers. J. Clin. Microbiol., 38(11): 4080-4085.

135. Roth, A., Fischer, M., Hamid, M.E., Michalke, S., Ludwig, W. and Mauch, H. (1998) Differentiation of phylogenetically related slowly growing mycobacteria based on 16S-23S rRNA gene internal transcribed spacer sequences. J. Clin. Microbiol., 36(1): 139-147.

136. Ngan, G.J.Y., Ng, L.M., Jureen, R., Lin, R.T.P. and Teo, J.W.P. (2011) Development of multiplex PCR assays based on the 16S-23S rRNA internal transcribed spacer for the detection of clinically relevant nontuberculous mycobacteria. Lett. Appl. Microbiol., 52(5): 546-554.

137. Howard, S.T., Oughton, M.T., Haddad, A. and Johnson, W.M. (1998) Absence of the genetic marker IS6110 from a strain of Mycobacterium tuberculosis isolated in Ontario. Can. J. Infect. Dis., 9(1): 48-53.

138. Frothingham, R., Hills, H.G. and Wilson, K.H. (1994) Extensive DNA sequence conservation throughout the Mycobacterium tuberculosis complex. J. Clin. Microbiol., 32(7): 1639-1643.

139. Roychowdhury, T., Mandal, S. and Bhattacharya, A. (2015) Analysis of IS 6110 insertion sites provide a glimpse into genome evolution of Mycobacterium tuberculosis. Sci. Rep., 5(1): 1-10.

140. Gonzalo-Asensio, J., Perez, I., Aguilo, N., Uranga, S., Pico, A., Lampreave, C., Cebollada, A., Otal, I., Samper, S. and Martin, C. (2018) New insights into the transposition mechanisms of IS6110 and its dynamic distribution between Mycobacterium tuberculosis complex lineages. PLoS Genet, 14(4): e1007282.

141. Lira, L.A.S., Santos, F.C.F., Carvalho, M.S.Z., Montenegro, R.A., Lima, J.F.C., Schindler, H.C. and Montenegro, L.M.L. (2013) Evaluation of a IS 6110-Taqman real-time PCR assay to detect Mycobacterium tuberculosis in sputum samples of patients with pulmonary TB. J. Appl. Microbiol., 114(4): 1103-1108.

142. Liu, H., Lian, L., Jiang, Y., Huang, M., Tan, Y., Zhao, X., Zhang, J., Yu, Q., Liu, J., Dong, H. and Lu, B. (2016) 
Identification of species of nontuberculous mycobacteria clinical isolates from 8 provinces of China. Biomed Res. Int., 2016: 2153910.

143. Varma-Basil, M., Garima, K., Pathak, R., Dwivedi, S.K.D., Narang, A., Bhatnagar, A. and Bose, M. (2013) Development of a novel PCR restriction analysis of the hsp65 gene as a rapid method to screen for the Mycobacterium tuberculosis complex and nontuberculous mycobacteria in high-burden countries. J. Clin. Microbiol., 51(4): 1165-1170.

144. Macente, S., Leite, C.Q.F., Santos, A.C.B., Siqueira, V.L.D., Machado, L.N.C., Marcondes, N.R., Hirata, M.H., Hirata, R.D.C. and Cardoso, R.F. (2013) Evaluation of hsp65 nested PCR-restriction analysis (PRA) for diagnosing tuberculosis in a high burden country. Biomed Res. Int., 2013: 391549.

145. Bannalikar, A.S. and Verma, R. (2006) Detection of Mycobacterium avium and M. tuberculosis from human sputum cultures by PCR-RFLP analysis of hsp65 gene and pncA PCR. Indian J. Med. Res., 123(2): 165-172.

146. Singh, A. and Kashyap, V.K. (2012) Specific and rapid detection of Mycobacterium tuberculosis complex in clinical samples by polymerase chain reaction. Interd. Persp. Infect. Dis., 2012: 654694.

147. Takewaki, S.I., Okuzumi, K., Manabe, I., Tanimura, M., Miyamura, K., Nakahara, K.I., Yazaki, Y., Ohkubo, A. and Nagai, R. (1994) Nucleotide sequence comparison of the mycobacterial dnaJ gene and PCR-restriction fragment length polymorphism analysis for identification of mycobacterial species. Int. J. Syst. Evol. Microbiol., 44(1): 159-166.

148. Hida, Y., Hisada, K., Shimada, A., Yamashita, M., Kimura, H., Yoshida, H., Iwasaki, H. and Iwano, M. (2012) Rapid detection of the Mycobacterium tuberculosis complex by use of quenching probe PCR (geneCube) J. Clin. Microbiol., 50(11): 3604-3608.

149. Yamada-Noda, M., Ohkusu, K., Hata, H., Shah, M.M., Nhung, P.H., Sun, X.S., Hayashi, M. and Ezaki, T. (2007) Mycobacterium species identification a new approach via dnaJ gene sequencing. Syst. Appl. Microbiol., 30(6): 453-462.

150. Soini, H.A.N., Skurnik, M.I.K., Liippo, K.A.R., Tala, E. and Viljanen, M.K. (1992) Detection and identification of mycobacteria by amplification of a segment of the gene coding for the 32-kilodalton protein. J. Clin. Microbiol., 30(8): 2025-2028.

151. Soini, H., Böttger, E.C. and Viljanen, M.K. (1994) Identification of mycobacteria by PCR-based sequence determination of the 32-kilodalton protein gene. J. Clin. Microbiol., 32(12): 2944-2947.

152. Ringuet, H., Akoua-Koffi, C., Honore, S., Varnerot, A., Vincent, V., Berche, P., Gaillard, J.L. and Pierre-Audigier, C. (1999) hsp65 sequencing for identification of rapidly growing mycobacteria. J. Clin. Microbiol., 37(3): 852-857.

153. Ghadage, D.P., Muley, V.A., Pednekar, S. and Bhore, A.V. (2014) Evaluation of polymerase chain reaction using primer MPB 64 for diagnosis of clinically suspected cases of extrapulmonary tuberculosis. J. Sci. Soc., 41(2): 89.

154. Kusum, S., Manish, M., Kapil, G., Aman, S., Pallab, R. and Kumar, S. (2012) Evaluation of PCR using MPB64 primers for rapid diagnosis of tuberculosis meningitis. Open Access Sci. Rep., 1(3): 1e4.

155. Arora, J., Kumar, G., Verma, A.K., Bhalla, M., Sarin, R. and Myneedu, V.P. (2015) Utility of MPT64 antigen detection for rapid confirmation of Mycobacterium tuberculosis complex. J. Glob. Infect. Dis., 7(2): 66-69.

156. Singh, K., Kumari, R., Tripathi, R., Gupta, A. and Anupurba, S. (2019) Mutation in MPT64 gene influencing diagnostic accuracy of SD Bioline assay (capilia). $B M C$ Infect. Dis., 19(1): 1048.

157. Martin, A., Bombeeck, D., Fissette, K., de Rijk, P., Hernández-Neuta, I., Del Portillo, P. and Palomino, J.C. (2011) Evaluation of the BD MGIT TBc Identification Test (TBc ID), a rapid chromatographic immunoassay for the detection of Mycobacterium tuberculosis complex from liquid culture. J. Microbiol. Methods., 84(2): 255-257.

158. Malhotra, V., Agrawal, R., Duncan, T.R., Saini, D.K. and Clark-Curtiss, J.E. (2015) Mycobacterium tuberculosis response regulators, DevR and NarL, interact in vivo and co-regulate gene expression during aerobic nitrate metabolism. J. Biol. Chem., 290(13): 8294-8309.

159. Sahni, A.K., Singh, S.P., Kumar, A. and Khan, I.D. (2013) Comparison of IS6110 and 'short fragment'devR (Rv3133c) gene targets with phenotypic methods for diagnosis of Mycobacterium tuberculosis. Med. J. Forces India, 69(4): 341-344.

160. Kataria, P., Kumar, A., Bansal, R., Sharma, A., Gupta, V., Gupta, A., Singh, R. and Sharma, K. (2015) devR PCR for the diagnosis of intraocular tuberculosis. Ocul. Immunol. Inflamm., 23(1): 47-52.

161. Domogalla, J., Prodinger, W.M., Blum, H., Krebs, S., Gellert, S., Müller, M., Neuendorf, E., Sedlmaier, F. and Büttner, M. (2013) Region of difference 4 in alpine Mycobacterium caprae isolates indicates three variants. $J$. Clin. Microbiol., 51(5): 1381-1388.

162. Reddington, K., O'Grady, J., Dorai-Raj, S., Niemann, S., van Soolingen, D. and Barry, T. (2011) A novel multiplex real-time PCR for the identification of mycobacteria associated with zoonotic tuberculosis. PLoS One, 6(8): e23481

163. Orloski, K., Robbe-Austerman, S., Stuber, T., Hench, B. and Schoenbaum, M. (2018) Whole genome sequencing of Mycobacterium bovis isolated from livestock in the United States, 1989-2018. Front. Vet. Sci., 5: 253.

164. Price-Carter, M., Brauning, R., de Lisle, G.W., Livingstone, P., Neill, M., Sinclair, J., Paterson, B., Atkinson, G., Knowles, G., Crews, K. and Crispell, J. (2018) Whole genome sequencing for determining the source of Mycobacterium bovis infections in livestock herds and wildlife in New Zealand. Front. Vet. Sci., 5: 272.

165. Wirth, T., Hildebrand, F., Allix-Béguec, C., Wölbeling, F., Kubica, T., Kremer, K., Van Soolingen, D., RüschGerdes, S., Locht, C., Brisse, S. and Meyer, A. (2008) Origin, spread and demography of the Mycobacterium tuberculosis complex. PLoS Pathog., 4(9): e1000160.

166. Grant, A., Arnold, C., Thorne, N., Gharbia, S. and Underwood, A. (2008) Mathematical modelling of Mycobacterium tuberculosis VNTR loci estimates a very slow mutation rate for the repeats. J. Mol. Evol., 66(6): 565-574.

167. Otchere, I.D., Van Tonder, A.J., Asante-Poku, A., Sánchez-Busó, L., Coscollá, M., Osei-Wusu, S., Asare, P., Aboagye, S.Y., Ekuban, S.A., Yahayah, A.I. and Forson, A. (2019) Molecular epidemiology and whole genome sequencing analysis of clinical Mycobacterium bovis from Ghana. PLoS One, 14(3): e0209395.

168. Collins, D.M. and De Lisle, G.W. (1985) DNA restriction endonuclease analysis of Mycobacterium bovis and other members of the tuberculosis complex. J. Clin. Microbiol., 21(4): 562-564.

169. Collins, D.M., Radford, A.J., de Lisle, G.W. and BillmanJacobe, H. (1994) Diagnosis and epidemiology of bovine tuberculosis using molecular biological approaches. Vet. Microbiol., 40(1-2): 83-94.

170. Collins, D.M., de Lisle, G.W., Collins, J.D. and Costello, E. (1994) DNA restriction fragment typing of Mycobacterium bovis isolates from cattle and badgers in Ireland. Vet. Rec., 134(26): 681-682.

171. Collins, D.M., Erasmuson, S.K., Stephens, D.M., Yates, G.F. and De Lisle, G.W (1993) DNA fingerprinting of Mycobacterium bovis strains by restriction fragment analysis and hybridization with insertion elements IS1081 and IS6110. J. Clin. Microbiol., 31(5): 1143-1147.

172. Zhang, Y.A.N., Mazurek, G.H., Cave, M.D., Eisenach, K.D., Pang, Y., Murphy, D.T. and Wallace, R.J. (1992) DNA polymorphisms in strains of Mycobacterium tuberculosis analyzed by pulsed-field gel electrophoresis: A tool for 
epidemiology. J. Clin. Microbiol., 30(6): 1551-1556.

173. Bakuła, Z., Brzostek, A., Borówka, P., Żaczek, A., SzulcKiełbik, I., Podpora, A., Parniewski, P., Strapagiel, D., Dziadek, J., Proboszcz, M. and Bielecki, J. (2018) Molecular typing of Mycobacterium kansasii using pulsed-field gel electrophoresis and a newly designed variable-number tandem repeat analysis. Sci. Rep., 8(1): 1-11.

174. Shin, J.I., Shin, S.J. and Shin, M.K. (2020) Differential genotyping of Mycobacterium avium complex and its implications in clinical and environmental epidemiology. Microorganisms, 8(1): 98.

175. Feizabadi, M.M., Robertson, I.D., Cousins, D.V. and Hampson, D.J. (1996) Genomic analysis of Mycobacterium bovis and other members of the Mycobacterium tuberculosis complex by isoenzyme analysis and pulsed-field gel electrophoresis. J. Clin. Microbiol., 34(5): 1136-1142.

176. Brosch, R., Gordon, S.V., Garnier, T., Eiglmeier, K., Frigui, W., Valenti, P., Dos Santos, S., Duthoy, S., Lacroix, C., Garcia-Pelayo, C. and Inwald, J.K. (2007) Genome plasticity of BCG and impact on vaccine efficacy. Proc. Natl. Acad. Sci. U. S. A., 104(13): 5596-5601.

177. Garnier, T., Eiglmeier, K., Camus, J.C., Medina, N., Mansoor, H., Pryor, M., Duthoy, S., Grondin, S., Lacroix, C., Monsempe, C. and Simon, S. (2003) The complete genome sequence of Mycobacterium bovis. Proc. Natl. Acad. Sci. U. S. A., 100(13): 7877-7882.

178. Bryant, J.M., Schürch, A.C., Van Deutekom, H., Harris, S.R., De Beer, J.L., De Jager, V., Kremer, K., Van Hijum, S.A., Siezen, R.J., Borgdorff, M. and Bentley, S.D. (2013) Inferring patient to patient transmission of Mycobacterium tuberculosis from whole genome sequencing data. $B M C$ Infect. Dis., 13(1): 110.

179. Butcher, P.D. (2004) Microarrays for Mycobacterium tuberculosis. Tuberculosis (Edinb), 84(3-4): 131-137.

180. Holloway, A.J., Van Laar, R.K., Tothill, R.W. and Bowtell, D.D. (2002) Options available from start to finish for obtaining data from DNA microarrays II. Nat. Genet., 32(4): 481-489.

181. Gordon, S.V., Bottai, D., Simeone, R., Stinear, T.P. and Brosch, R. (2009) Pathogenicity in the tubercle bacillus: Molecular and evolutionary determinants. Bioessays, 31(4): 378-388.

182. Voskuil, M.I., Schnappinger, D., Rutherford, R., Liu, Y. and Schoolnik, G.K. (2004) Regulation of the Mycobacterium tuberculosis PE/PPE genes. Tuberculosis (Edinb), 84(3-4): 256-262.

183. Müller, B., Hilty, M., Berg, S., Garcia-Pelayo, M.C., Dale, J., Boschiroli, M.L., Cadmus, S., Ngandolo, B.N.R., Godreuil, S., Diguimbaye-Djaibé, C. and Kazwala, R. (2009) African 1, an epidemiologically important clonal complex of Mycobacterium bovis dominant in Mali, Nigeria, Cameroon, and Chad. J. Bacteriol., 191(6): 1951-1960.

184. Berg, S., Garcia-Pelayo, M.C., Müller, B., Hailu, E., Asiimwe, B., Kremer, K., Dale, J., Boniotti, M.B., Rodriguez, S., Hilty, M. and Rigouts, L. (2011) African 2, a clonal complex of Mycobacterium bovis epidemiologically important in East Africa. J. Bacteriol., 193(3): 670-678.

185. Smith, N.H., Berg, S., Dale, J., Allen, A., Rodriguez, S., Romero, B., Matos, F., Ghebremichael, S., Karoui, C., Donati, C. and da Conceicao Machado, A. (2011) European 1: A globally important clonal complex of Mycobacterium bovis. Infect. Genet. Evol., 11(6): 1340-1351.

186. Southern, E.M. (1975) Detection of specific sequences among DNA fragments separated by gel electrophoresis. $J$. Mol. Biol, 98(3): 503-517.

187. Braden, C.R., Crawford, J.T. and Schable, B.A. (2002) Quality assessment of Mycobacterium tuberculosis genotyping in a large laboratory network. Emerg. Infect. Dis., 8(11): 1210-1215.

188. Romano, M.I., Alito, A., Fisanotti, J.C., Bigi, F., Kantor, I., Cicuta, M.E. and Cataldi, A. (1996) Comparison of different genetic markers for molecular epidemiology of bovine tuberculosis. Vet. Microbiol., 50(1-2): 59-71.

189. Aranaz, A., Liébana, E., Mateos, A., Domínguez, L. and Cousins, D. (1998) Restriction fragment length polymorphism and spacer oligonucleotide typing: A comparative analysis of fingerprinting strategies for Mycobacterium bovis. Vet. Microbiol., 61(4): 311-324.

190. Costello, E., O'Grady, D., Flynn, O., O'Brien, R., Rogers, M., Quigley, F., Egan, J. and Griffin, J. (1999) Study of restriction fragment length polymorphism analysis and spoligotyping for epidemiological investigation of Mycobacterium bovis infection. J. Clin. Microbiol., 37(10): 3217-3222.

191. Kamerbeek, J., Schouls, L.E.O., Kolk, A., Van Agterveld, M., Van Soolingen, D., Kuijper, S., Bunschoten, A., Molhuizen, H., Shaw, R., Goyal, M. and van Embden, J. (1997) Simultaneous detection and strain differentiation of Mycobacterium tuberculosis for diagnosis and epidemiology. J. Clin. Microbiol., 35(4): 907-914.

192. Groenen, P.M., Bunschoten, A.E., Soolingen, D.V. and Errtbden, J.D.V. (1993) Nature of DNA polymorphism in the direct repeat cluster of Mycobacterium tuberculosis; application for strain differentiation by a novel typing method. Mol. Microbiol., 10(5): 1057-1065.

193. Barandiaran, S., Vivot, M.M., Perez, A.M., Cataldi, A.A. and Zumárraga, M.J. (2015) Bovine tuberculosis in domestic pigs: Genotyping and distribution of isolates in Argentina. Res. Vet. Sci., 103: 44-50.

194. Amato, B., Di Marco Lo Presti, V., Gerace, E., Capucchio, M.T., Vitale, M., Zanghì, P. and Boniotti, M.B. (2017) Molecular epidemiology of Mycobacterium tuberculosis complex strains isolated from livestock and wild animals in Italy suggests the need for a different eradication strategy for bovine tuberculosis. Transbound. Emerg. Dis., 65(2): e416-e424.

195. Demay, C., Liens, B., Burguière, T., Hill, V., Couvin, D., Millet, J., Mokrousov, I., Sola, C., Zozio, T. and Rastogi, N. (2012) SITVITWEB a publicly available international multimarker database for studying Mycobacterium tuberculosis genetic diversity and molecular epidemiology. Infect. Genet. Evol., 12(4): 755-766.

196. Smith, N.H. and Upton, P. (2012) Naming spoligotype patterns for the RD9-deleted lineage of the Mycobacterium tuberculosis complex; www. Mbovis. org. Infect. Genet. Evol., 12(4): 873-876.

197. Ghielmetti, G., Scherrer, S., Friedel, U., Frei, D., Suter, D., Perler, L. and Wittenbrink, M.M. (2017) Epidemiological tracing of bovine tuberculosis in Switzerland, multilocus variable number of tandem repeat analysis of Mycobacterium bovis and Mycobacterium caprae. PLoS One, 12(2): e0172474

198. Andrievskaia, O., Turcotte, C., Berlie-Surujballi, G., Battaion, H. and Lloyd, D. (2018) Genotypes of Mycobacterium bovis strains isolated from domestic animals and wildlife in Canada in 1985-2015. Vet. Microbiol., 214: 44-50.

199. Supply,P., Lesjean, S., Savine, E., Kremer, K., Van Soolingen, D. and Locht, C. (2001) Automated high-throughput genotyping for study of global epidemiology of Mycobacterium tuberculosis based on mycobacterial interspersed repetitive units. $J$. Clin. Microbiol., 39(10): 3563-3571.

200. Goyal, M., Young, D., Zhang, Y., Jenkins, P.A. and Shaw, R.J. (1994) PCR amplification of variable sequence upstream of katG gene to subdivide strains of Mycobacterium tuberculosis complex. J. Clin. Microbiol., 32(12): 3070-3071.

201. Skuce, R.A., McCorry, T.P., McCarroll, J.F., Roring, S.M., Scott, A.N., Brittain, D., Hughes, S.L., Hewinson, R.G. and Neill, S.D. (2002) Discrimination of Mycobacterium tuberculosis complex bacteria using novel VNTR-PCR targets. Microbiology, 148(2): 519-528.

202. Supply, P., Magdalena, J., Himpens, S. and Locht, C. (1997) Identification of novel intergenic repetitive units in a mycobacterial two-component system operon. Mol. Microbiol., 
26(5): 991-1003.

203. Milian-Suazo, F., Garcia-Casanova, L., Robbe-Austerman, S., Canto-Alarcon, G.J., Barcenas-Reyes, I., Stuber, T., Rodriguez-Hernandez, E. and Flores-Villalva, S. (2016) Molecular relationship between strains of $M$. bovis from Mexico and those from countries with free trade of cattle with Mexico. PLoS One, 11(5): e0155207.

204. Vargas, A.N., Suazo, F.M., Alarcón, G.J.C., Venegas, Y.R., Solorio, R.G., Hernández, E.R. and Martìnez, O.P. (2016) Genetic diversity based on MIRU-VNTR profile of isolates of Mycobacterium bovis from Mexican cattle. Prev. Vet. Med., 131: 75-78.

205. Hermans, P.W., van Soolingen, D.I.C. and Van Embden, J.D. (1992) Characterization of a major polymorphic tandem repeat in Mycobacterium tuberculosis and its potential use in the epidemiology of Mycobacterium kansasii and Mycobacterium gordonae. J. Bacteriol., 174(12): 4157-4165.

206. Glennon, M., Jäger, B., Dowdall, D., Maher, M., Dawso, M., Quigley, F., Costello, E. and Smith, T. (1997) PCR-based fingerprinting of Mycobacterium bovis isolates. Vet. Microbiol., 54(3-4): 235-245.

207. Kremer, K., Van Soolingen, D., Frothingham, R., Haas, W.H., Hermans, P.W.M., Martin, C., Palittapongarnpim, P., Plikaytis, B.B., Riley, L.W., Yakrus, M.A. and Musser, J.M. (1999) Comparison of methods based on different molecular epidemiological markers for typing of Mycobacterium tuberculosis complex strains: Interlaboratory study of discriminatory power and reproducibility. J. Clin. Microbiol., 37(8): 2607-2618.

208. Plikaytis, B.B., Crawford, J.T., Woodley, C.L., Butler, W.R., Eisenach, K.D., Cave, M.D. and Shinnick, T.M. (1993) Rapid, amplification-based fingerprinting of Mycobacterium tuberculosis. Microbiology, 139(7): 1537-1542.

209. Van Belkum, A. (1994) Genetic typing of medically important non-viral microorganisms by polymerase chain reaction-mediated DNA fingerprinting. Clin. Microbiol. Rev., 7: 174-184.

210. Palittapongarnpim, P., Chomyc, S., Fanning, A. and Kunimoto, D. (1993) DNA fragment length polymorphism analysis of Mycobacterium tuberculosis isolates by arbitrarily primed polymerase chain reaction. J. Infect Dis., 167(4): 975-978.

211. Milian-Suazo, F., Salman, M.D., Black W.C. $4^{\text {th }}$., Triantis, J.M., Ramirez, C., Payeur, J.B. and Torres, M.C. (2000) Molecular epidemioloic analysis of Mycobacterium bovis isolates from Mexico. Am. J. Vet. Res., 61(1): 90-95.

212. Wuzinski, M., Bak, A.K., Petkau, A., Demczuk, W.H.B., Soualhine, H. and Sharma, M.K. (2019) A multilocus sequence typing scheme for Mycobacterium abscessus complex (MAB-multilocus sequence typing) using whole-genome sequencing data. Int. J. Mycobacteriol., 8(3): 273.

213. Achtman, M. (2008) Evolution, population structure, and phylogeography of genetically monomorphic bacterial pathogens. Annu. Rev. Microbiol., 62: 53-70.

214. Pérez-Losada, M., Porter, M.L., Viscidi, R.P. and Crandall, K.A. (2011) Multilocus sequence typing of pathogens. In: Genetics and Evolution of Infectious Diseases. Elsevier, Amsterdam, Netherlands. p503-521.

215. Bigi, F., Garcia-Pelayo, M.C., Nuñez-García, J., Peralta, A., Caimi, K.C., Golby, P., Hinds, J., Cataldi, A., Gordon, S.V. and Romano, M.I. (2005) Identification of genetic markers for Mycobacterium pinnipedii through genome analysis. FEMS Microbiol. Lett., 248(2): 147-152.

216. Brodin, P., Eiglmeier, K., Marmiesse, M., Billault, A., Garnier, T., Niemann, S., Cole, S.T. and Brosch, R.
(2002) Bacterial artificial chromosome-based comparative genomic analysis identifies Mycobacterium microti as a natural ESAT-6 deletion mutant. Infect. Immun., 70(10): 5568-5578

217. Mostowy, S., Cousins, D. and Behr, M.A., (2004) Genomic interrogation of the dassie bacillus reveals it as a unique RD1 mutant within the Mycobacterium tuberculosis complex. J. Bacteriol., 186(1): 104-109.

218. Mostowy, S., Tsolaki, A.G., Small, P.M. and Behr, M.A. (2003) The in vitro evolution of BCG vaccines. Vaccine, 21(27-30): 4270-4274.

219. Talbot, E.A., Williams, D.L. and Frothingham, R. (1997) PCR identification of Mycobacterium bovis BCG. J. Clin. Microbiol., 35(3): 566-569.

220. Mostowy, S., Cousins, D., Brinkman, J., Aranaz, A. and Behr, M.A. (2002) Genomic deletions suggest a phylogeny for the Mycobacterium tuberculosis complex. J. Infect. Dis., 186(1): 74-80.

221. Brosch, R., Gordon, S.V., Marmiesse, M., Brodin, P., Buchrieser, C., Eiglmeier, K., Garnier, T., Gutierrez, C., Hewinson, G., Kremer, K. and Parsons, L.M. (2002) A new evolutionary scenario for the Mycobacterium tuberculosis complex. Proc. Nat. Acad. Sci., 99(6): 3684-3689.

222. Warren, R.M., Gey van Pittius, N.C., Barnard, M., Hesseling, A., Engelke, E., De Kock, M., Gutierrez, M.C., Chege, G.K., Victor, T.C., Hoal, E.G. and Van Helden, P.D. (2006) Differentiation of Mycobacterium tuberculosis complex by PCR amplification of genomic regions of difference. Int. J. Tuberc. Lung Dis., 10(7): 818-822.

223. Gordon, S.V., Brosch, R., Billault, A., Garnier, T., Eiglmeier, K. and Cole, S.T. (1999) Identification of variable regions in the genomes of tubercle bacilli using bacterial artificial chromosome arrays. Mol. Microbiol., 32(3): 643-655.

224. Scorpio, A. and Zhang, Y. (1996) Mutations in pncA, a gene encoding pyrazinamidase/nicotinamidase, cause resistance to the antituberculous drug pyrazinamide in tubercle bacillus. Nat. Med., 2(6): 662-667.

225. Abadia, E., Zhang, J., dos Vultos, T., Ritacco, V., Kremer, K., Aktas, E., Matsumoto, T., Refregier, G., van Soolingen, D., Gicquel, B. and Sola, C. (2010) Resolving lineage assignation on Mycobacterium tuberculosis clinical isolates classified by spoligotyping with a new high-throughput 3R SNPs based method. Infect. Genet. Evol., 10(7): 1066-1074.

226. Schürch, A.C., Kremer, K., Warren, R.M., Hung, N.V., Zhao, Y., Wan, K., Boeree, M.J., Siezen, R.J., Smith, N.H. and van Soolingen, D. (2011) Mutations in the regulatory network underlie the recent clonal expansion of a dominant subclone of the Mycobacterium tuberculosis Beijing genotype. Infect. Genet. Evol., 11(3): 587-597.

227. Smith, N.H., Gordon, S.V., de la Rua-Domenech, R., CliftonHadley, R.S. and Hewinson, R.G. (2006) Bottlenecks and broomsticks: The molecular evolution of Mycobacterium bovis. Nat. Rev. Microbiol., 4(9): 670-681.

228. Allen, A.R., Dale, J., McCormick, C., Mallon, T.R., Costello, E., Gordon, S.V., Hewinson, R.G., Skuce, R.A. and Smith, N.H. (2013) The phylogeny and population structure of Mycobacterium bovis in the British Isles. Infect. Genet. Evol., 20: 8-15.

229. Richter, E., Weizenegger, M., Rüsch-Gerdes, S. and Niemann, S. (2003) Evaluation of genotype MTBC assay for differentiation of clinical Mycobacterium tuberculosis complex isolates. J. Clin. Microbiol., 41(6): 2672-2675.

230. Cleaveland, S., Mlengeya, T., Kazwala, R.R., Michel, A., Kaare, M.T., Jones, S.L., Eblate, E., Shirima, G.M. and Packer, C. (2005) Tuberculosis in Tanzanian wildlife. $J$. Wildl. Dis., 41(2): 446-453. 